BNWL-1842

\title{
HELIUM COOLANT COMPATI BILITY WITH CANDIDATE FUSION REACTOR STRUCTURAL MATERIALS
}

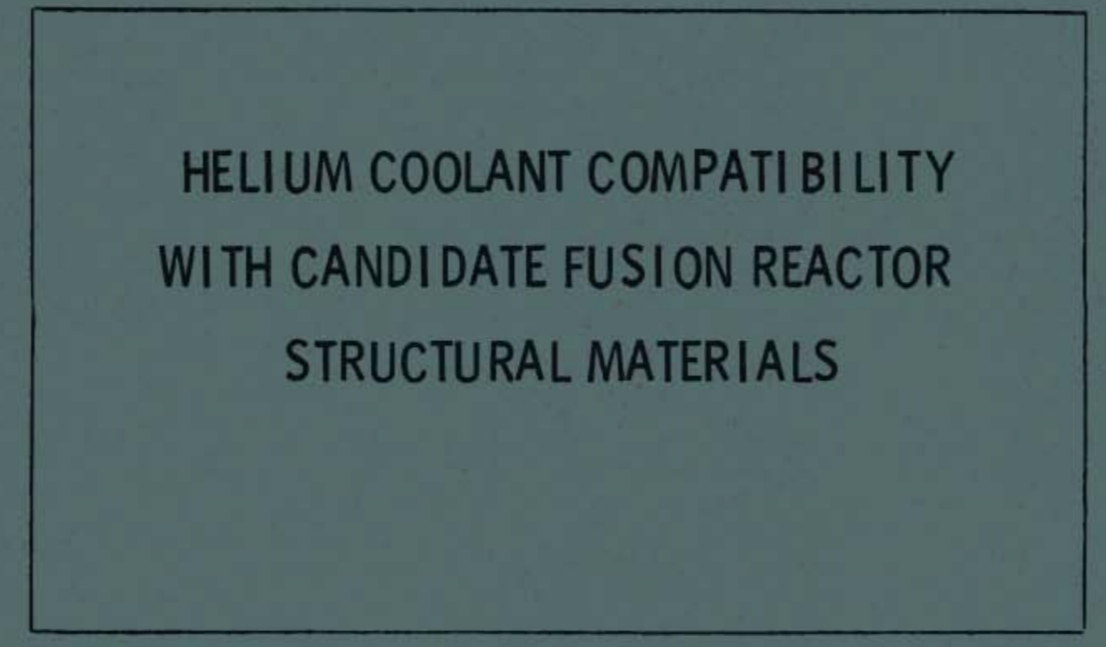

$\therefore$

JULY 15, 1974

Prepared for the U.S. Atomic Energy

Commission under Contract AT(45-1):1830 


\section{NOTICE}

The report was prepared as an account of work sponsored by the United States Government. Neither the United States nor the United States Atomic Energy Commission, nor any of their employees, nor any of their contractors, subcontractors, or their employees, makes any warranty, express or implied. or assumes any legal liability or responsibility for the accuracy, completeness or usefulness of any information, apparatus, product or process disclosed, or represents that its use would not infringe privately owned rights.

\section{PACIFIC NORTHWEST LABORATORY \\ operated by \\ BATTELLE \\ for the \\ U.S. ATOMIC ENERGY COMMISSION \\ Under Contract AT(45-1)-1830}

Printed in the United States of America

Available from

National Technical Information Service

U.S. Department of Commerce

5285 Port Royal Road

Springtield, Virginia 22151

Price: Printed Copy 54.00: Microfiche \$1.45 
BNWL-1842

HELIUM COOLANT COMPATIBILITY

WITH CANDIDATE FUSION REACTOR STRUCTURAL MATERIALS

by

L. A. Charlot

R. E. Westerman

July 15, 1974

BATTELLE

PACIFIC NORTHWEST LABORATORIES

RICHLAND, WASHINGTON 99352 
TABLE OF CONTENTS

$\begin{array}{ll}1.0 & \text { INTRODUCTION } \\ 2.0 & \text { BACKGROUND } \\ 2.1 & \text { MATERIALS } \\ 2.2 & \text { THERMODYNAMICS } \\ 2.2 .1 \quad \text { Oxides, Carbides, and Nitrides } & \text { of Niobium and Ilolybdenum } \\ 2.2 .2 \quad \begin{array}{l}\text { Terminal Solubilities of Oxygen, } \\ \text { Carbon, and Nitrogen in Nb and Mo }\end{array} \\ 2.2 .3 \quad \begin{array}{l}\text { Equilibria Between Nb and Mo Solid } \\ \text { Solutions and Contaminant Gas }\end{array} \\ 2.3 \quad \text { DIfFUSION }\end{array}$

$\begin{array}{lll}3.0 & \text { EFFECT OF ENVIRONMENT ON MECHANICAL PROPERTIES } & 10\end{array}$

3.1 STAINLESS STEELS 13

$\begin{array}{lll}3.2 & \text { REFRACTORY METALS } & 17\end{array}$

$\begin{array}{lll}3.2 .1 \mathrm{Nb}-0 x y g e n & 17\end{array}$

$\begin{array}{lll}3.2 .2 \mathrm{Nb}-1 \mathrm{Zr} \text {-Oxygen } & 18\end{array}$

$\begin{array}{lll}3.2 .3 \mathrm{Nb}-\mathrm{Ni} \text { trogen } & 19\end{array}$

3.2.4 Molybdenum Alloys - Oxygen 20

3.2.5 Molybdenum A1loys - Nitrogen 20

4.0 CONTAMINANT/ENVIRONMENT CRITERIA 20

4.1 STAINLESS STEELS 21

4.2 REFRACTORY METALS 23

5.0 CONTAMINANT CONTROL $\quad 24$

5.1 STAINLESS STEELS 24

5.2 REFRACTORY METALS 24

5.2.1 Rate of Surface Reactions 25

5.2.2 Rate of Bulk Diffusion 26

5.2.3 Limitation of Contaminant Availability 27

6.0 CONCLUSIONS 31

7.0 REFERENCES 32 


\section{HELIUM COOLANT COMPATIBILITY \\ WITH CANDIDATE FUSION REACTOR STRUCTURAL MATERIALS}

L. A. Charlot and R. E. Westerman

\subsection{INTRODUCTION}

Pressurized helium possesses several advantages as a CTR first wall and blanket cooling medium: it is chemically inert, it is not activated by neutron irradiation, and it does not interact with magnetic fields. Helium is currently being considered as the primary coolant in a number of current CTR design concepts. $(1-7)$ Reactive gaseous impurities present in a helium coolant stream, however, such as $\mathrm{O}_{2}, \mathrm{~N}_{2}, \mathrm{CO}_{\mathrm{x}}$, and $\mathrm{CH}_{\mathrm{x}}$, maintain their chemical activity in the inert helium gas. This is not the case in liquid metal coolants, such as lithium, where entrained impurities such as oxygen exhibit a reduced activity because of their affinity for the liquid metal. The ability of lithium to deoxidize niobium, for example, is well known and thermodynamically predictable.

The compatibility of helium, and its inevitable impurity loading, with CTR candidate structural materials must be given careful consideration before it is used in an actual system. The purpose of the present work is to define the impurity level limits in selected CTR candidate structural alloys, consistent with retention of satisfactory mechanical properties; to describe the contaminant sources in a hypothetical CTR system and their relative importance; and to outline the operational procedures required to preserve the engineering properties of the materials over their projected reactor service lifetimes.

A11 experimental results used in the present work were derived from the literature.

\subsection{BACKGROUND}

\subsection{MATERIALS}

First generation fusion reactors will almost certainly rely on stainless steels for their basic structures, with the maximum operating reactor temperature of $600^{\circ} \mathrm{C}$ to $650^{\circ} \mathrm{C}$. As reactor feasibility is demonstrated, the materials and designs will evolve to take advantage of the 
high temperatures and concomitant high thermal efficiencies irherent in the plasma. Materials with high temperature mechanical properties superior to stainless steels will be required for advanced CTR applications, such as nickel-base superalloys and, eventually, refractory-metal base alloys.

When a stainless steel is used in a corrosive environment, its integrity is dependent on the development of an adherent, protective, chromium-rich scale which results from an appropriate alloy composition. Also, the mechanical properties of stainless steel generally do not permit their application in load-bearing structures at temperatures so high that the corrosion rates become intolerable. On the other hand, at the very high temperatures typical of refractory metal applications, the rate of chemical reactions and internal contaminant diffusion become so fast that the metal approaches equilibrium with its environment relatively rapidly.

The materials considered in the present analys is are selected stainless steels, $\mathrm{Nb}$ and Nb-base alloys, and Mo and Mo-base alloys. The $\mathrm{Nb}$-base alloys approximate the characteristics of the other Group VA elements considered for CTR applications, Ta and $V$, with their generally high contaminant terminal solubilities and relatively stable compound formation. The Mo-base alloys roughly represent the behavior of the other refractory Group VIA Metals, $\mathrm{Cr}$ and W.

The great majority of present day refractory metal alloys contain reactive metal alloying elements, i.e., elements having substantially greater negative free energies of formation of carbides, nitrides, and oxides than does the matrix element. Examples are $\mathrm{Zr}$ in $\mathrm{Nb}$ alloys ( $\mathrm{Nb}-1 \mathrm{Zr}$ ), $\mathrm{Ti}$ and $\mathrm{Zr}$ in Mo alloys (TZM), and $\mathrm{Hf}$ in $\mathrm{W}$ alloys. Presence of these reactive alloy additions can exert a profound effect on the thermodynamic relationships between reactive gas species and the metal, the kinetics of gas-metal reactions, and the post-exposure mechanical properties of the metal. When refractory metals are eventually used in CTR structures, they will most likely be in the form of such alloys. For this reason, the $\mathrm{Nb}-1 \mathrm{Zr}$ alloys and the Mo-Ti-Zr alloy (TZM) were considered relevant to the present work.

\subsection{THERMODYNAMICS}

Stainless steels, used at temperatures to about $800^{\circ} \mathrm{C}$, rely on the protective nature and chemical stability of corrosion product films to 
maintain the integrity of the substrate. Refractory metal alloys, which do not generally form protective films and which are intended for use at temperatures above the upper limit for stainless steels, cannot rely on slow kinetics of contaminant pickup and internal distribution. The result is that the refractory metals will tend to reach equilibrium with the reactive gases in the environment at some time during the service life of the structural component. A knowledge of the thermodynamic relationships describing the reactions between reactive refractory metals and gas impurities is necessary in order to define the tolerable impurity levels in the gas, i.e., those impurity concentrations that are in equilibrium with an acceptable impurity level in the metal.

Included in this section are the thermodynamic free energies of compound formation for oxides, carbides, and nitrides of niobium and molybdenum; terminal solubility data for the compound phase-solid solution; and pressure-temperature-composition for contaminant/solid solution equilibria. Also included is a summary of diffusivity data for oxygen, nitrogen, and carbon in niobium and molybdenum, since these kinetic data relate to the distribution of contaminant within the metal.

Hydrogen is not considered in this study, as its entry into the metal is a reversible process at elevated temperature, and it presents problems only in the case of high partial pressures in the gas phase and its retention in the metal to low temperatures.

\subsubsection{Oxides, Carbides, and Nitrides of $\mathrm{Nb}$ and Mo}

The thermodynamic data cited in this report are taken from the extensive review and experimental work of Fromm $(8,9,10)$ and from the thermodynamic tables compiled by Schick, (11) and Kubaschewski and Evans. (12) Figures 1 and 2 show the free energies of formation of stoichiometric compounds as a function of temperature. The thermodynamic stability of these compounds increase as the free energy of formation decreases, as shown in Table 1 for the oxides of zirconium, titanium, niobium and molybdenum. The equilibrium partial pressures of oxygen and the corresponding $\mathrm{H}_{2} \mathrm{O} / \mathrm{H}_{2}$ ratios are also presented in the table. It is obvious that the metals listed will all oxidize at extremely low oxygen partial pressures. 


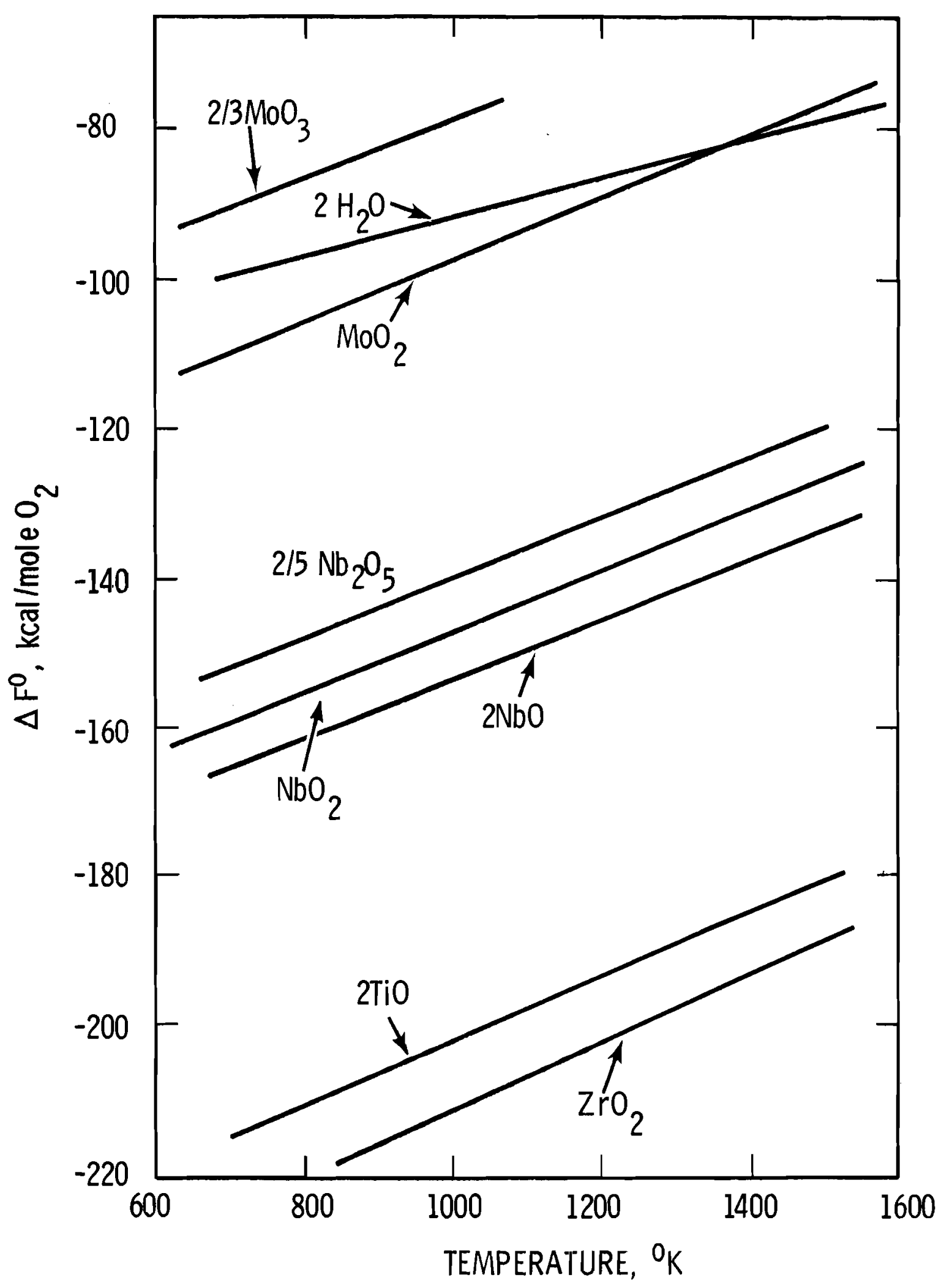

Figure 1 


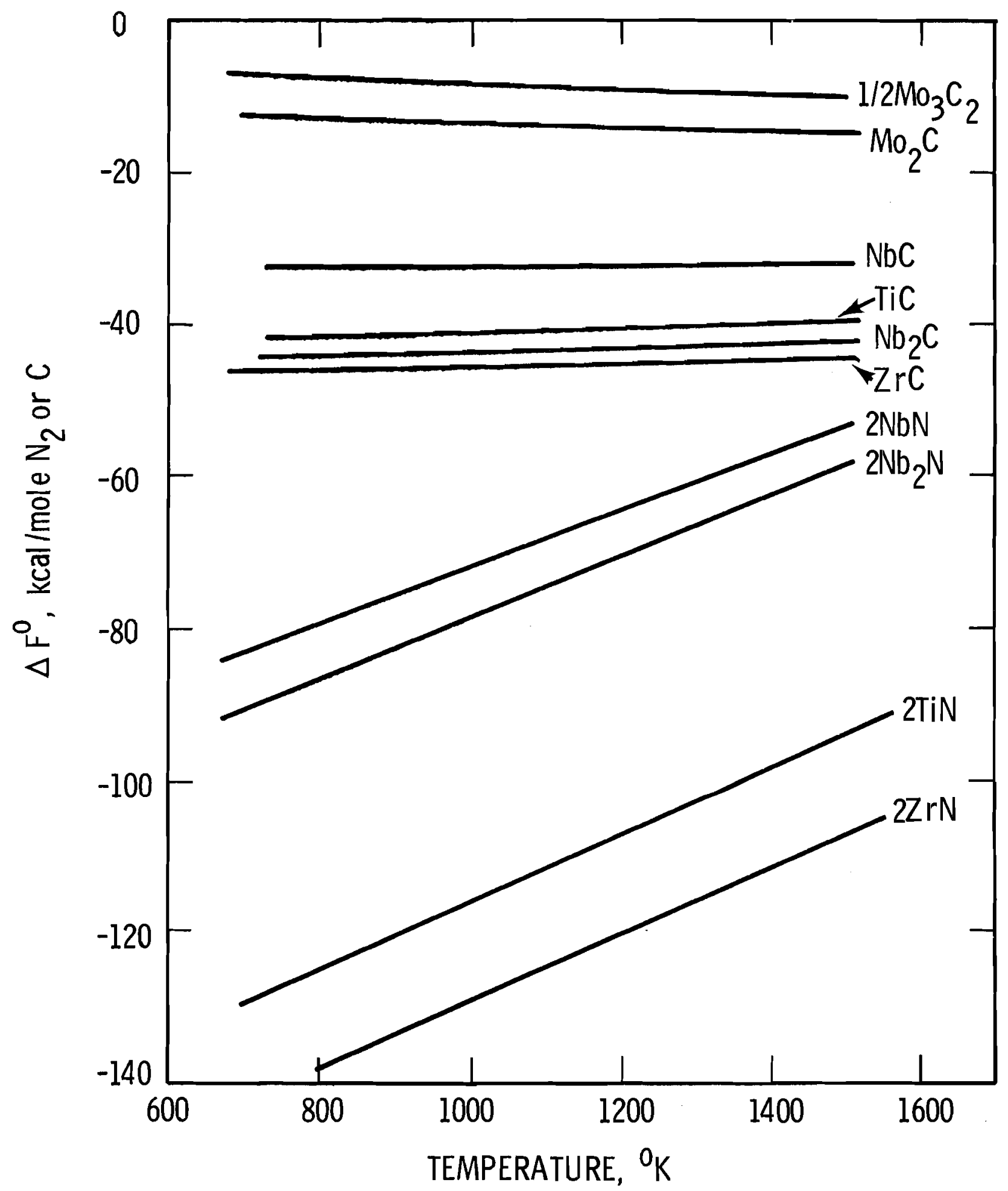

Figure 2

Free Energy of Formation 


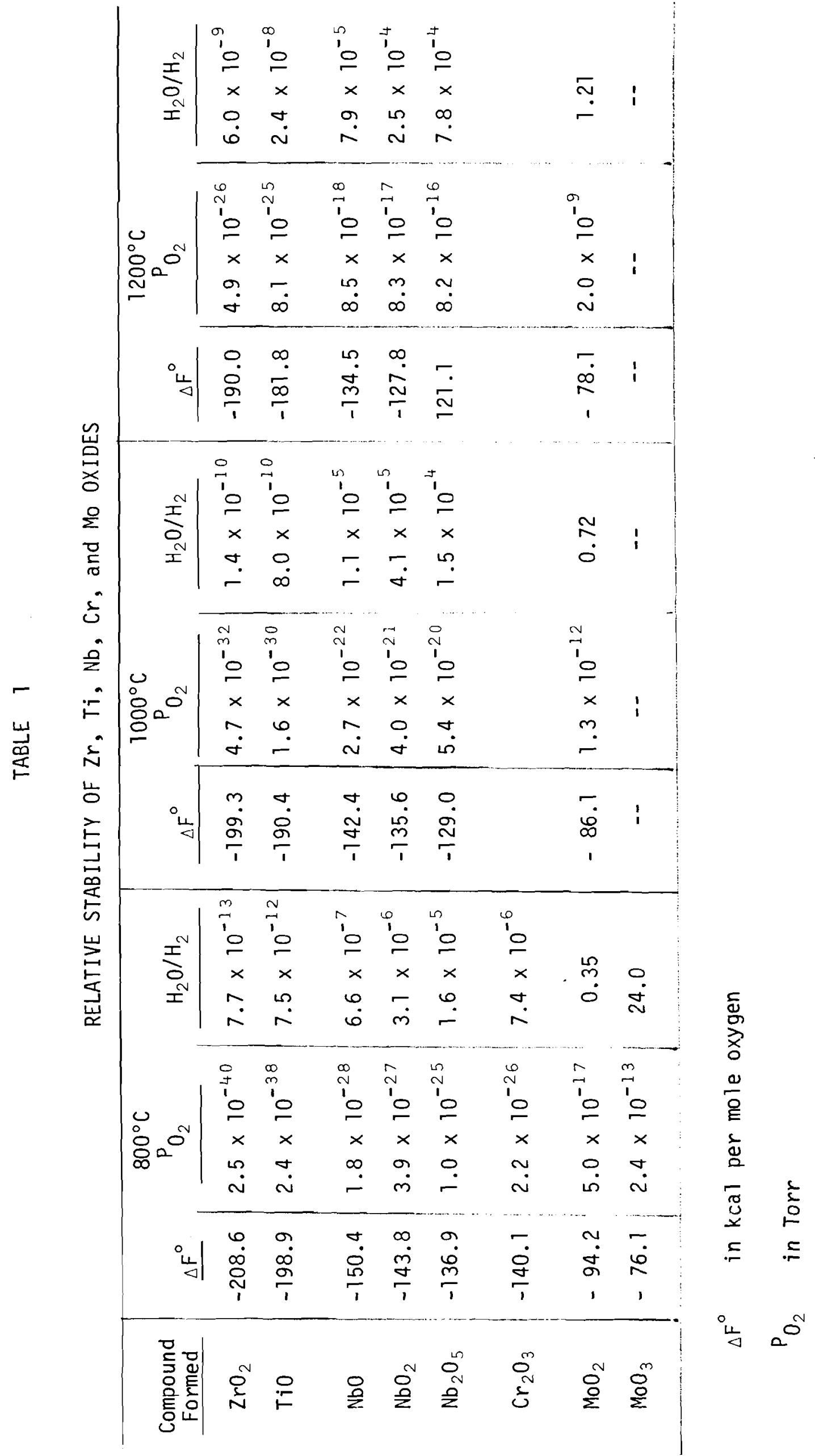




\subsubsection{Terminal Solubilities of Oxygen, Carbon, and Nitrogen in $\mathrm{Nb}$ and Mo}

Figures 3 and 4 show the concentration of interstitial contamination in the metal in equilibrium with the corresponding stoichiometric compound as a function of temperature. Fromm's relationships have been used since they represent a convenient compilation of the available experimental data. (9)

These data are strictly applicable only to the pure metals, as addition of a more reactive alloy ingredient (such as $\mathrm{Zr}$ or $\mathrm{Hf}$ ) can alter the terminal solubility.

\subsubsection{Equilibria Between $\mathrm{Nb}$ and Mo Sol id Solutions and Contaminant Gas}

The mechanical properties of refractory metals can be strongly affected at contaminant levels much lower than those corresponding to the terminal solubilities. For this reason, the equilibria between contaminants in solution in the metal and in the gas phase as a function of pressure and temperature become the critical thermodynamic criteria for compatibility.

Fromm $^{(9,10)}$ lists the equations describing the pressuretemperature-composition equilibria for the various interstitial solid solutions in $\mathrm{Nb}$ and Mo. The equations relevant to the present work are shown in Table 2. Equation 1 was used to determine the equilibrium pressure of oxygen

\section{TABLE 2}

EQUILIBRIA OF NIOBIUM AND MOLYBDENUM

SOLID SOLUTIONS IN VARIOUS GAS ATMOSPHERES

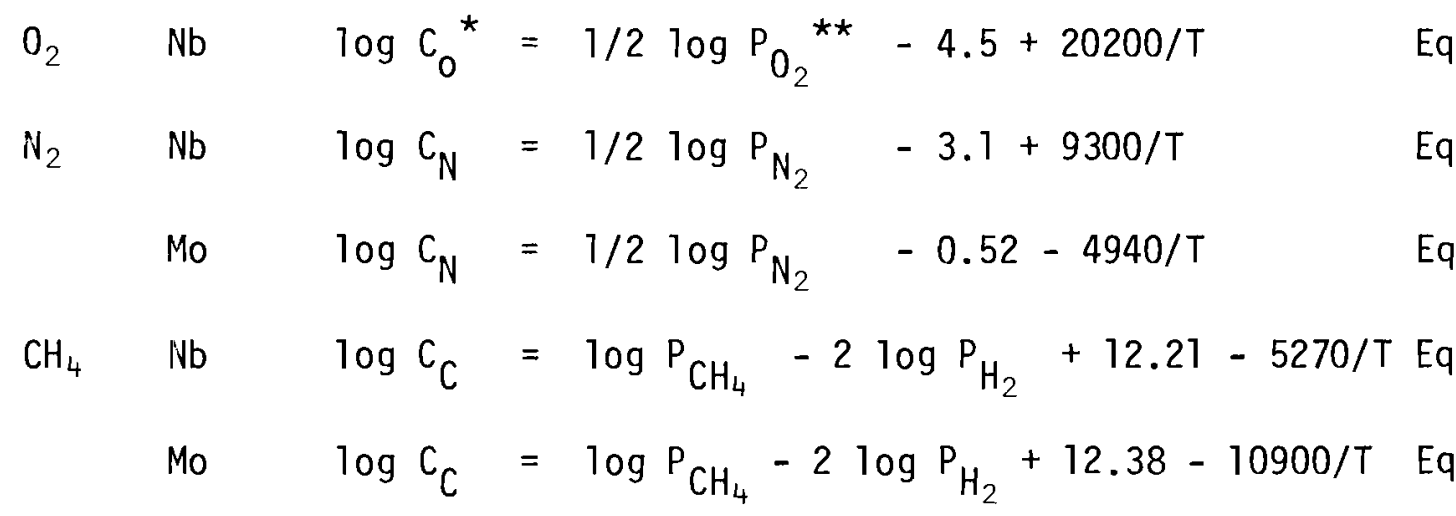

Concentration in atomic percent

Pressure in Torr 


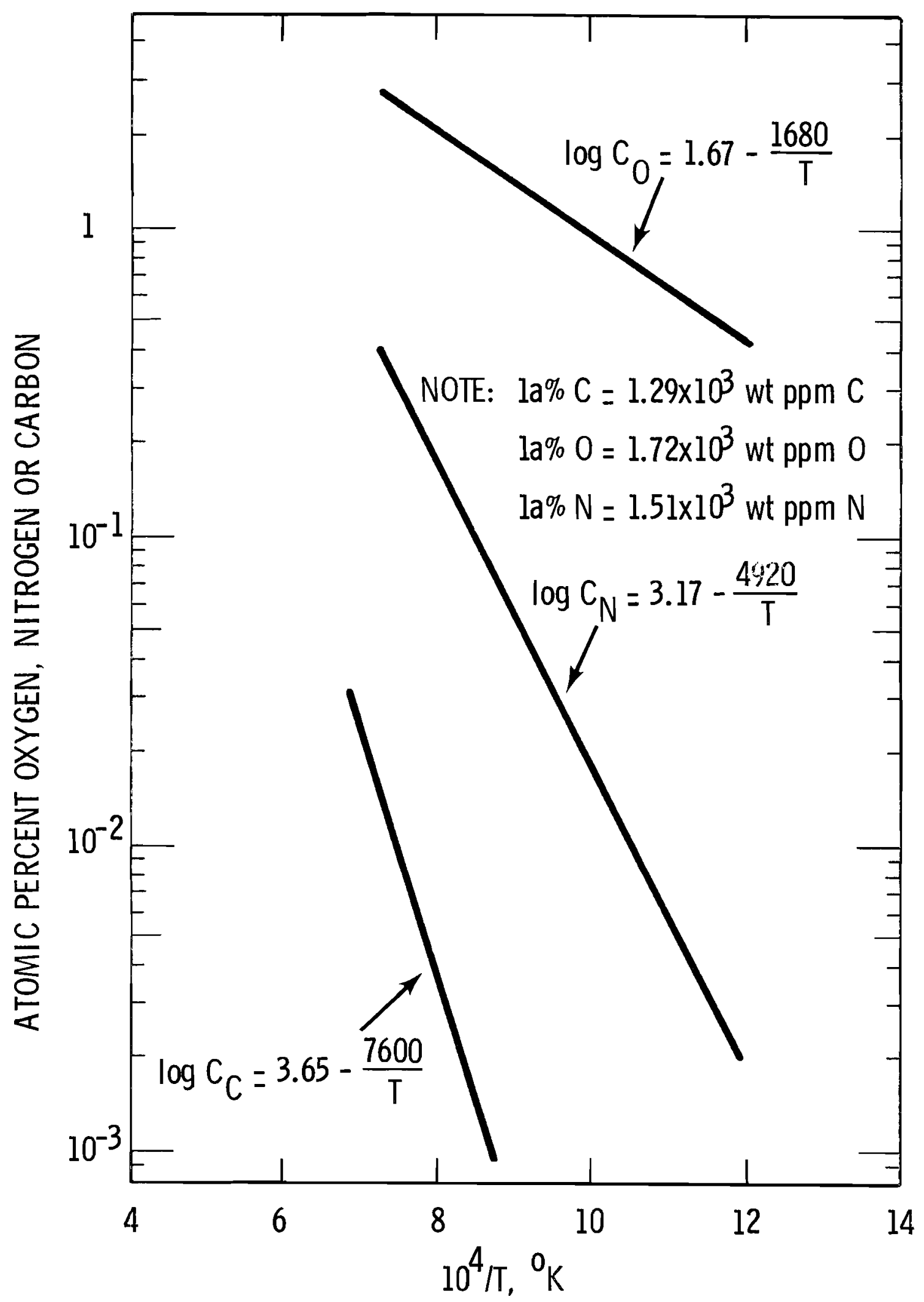

Figure 3

High Temperature Terminal Solubilities of Oxygen, Nitrogen and Carbon in Niobium 


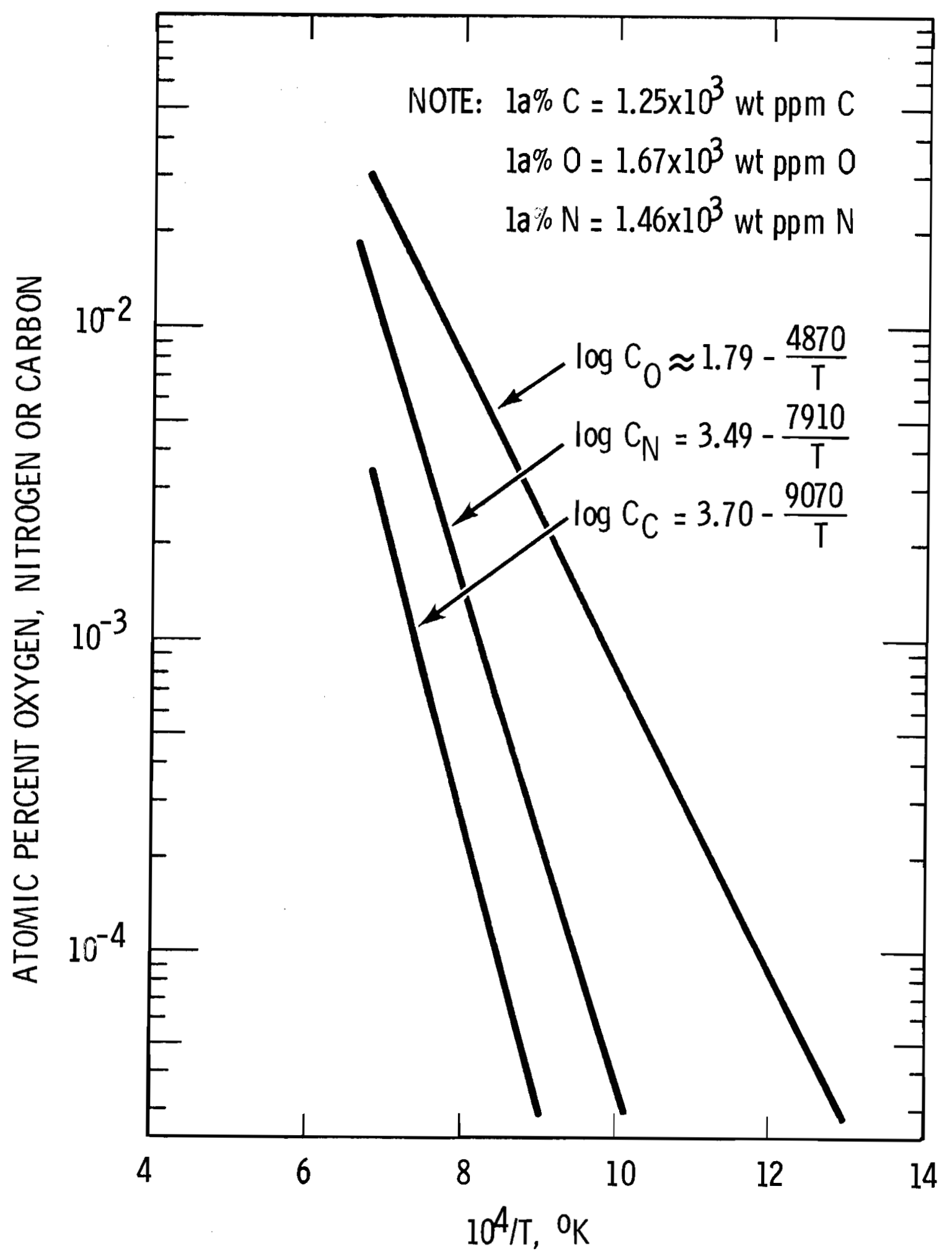

Figure 4

High Temperature Terminal Solubility

of Oxygen, Nitrogen and Carbon in Molybdenum 
over nloblum containing oxygen in solid solution up to terminal solubility at three temperatures (Figure 5 ). The terminal solubility curve for the formation of $\mathrm{NbO}$ was calculated from $\log c_{0}=1.67-\frac{1680}{T}$, where $C_{0}$ is the atom percent oxygen in niobium and $T$ is the absolute temperature. $\left({ }^{9}\right)$

Figure 5 graphically $i 11$ ustrates the extremely low pressures of gaseous oxygen in equilibrium with substantial quantities of oxygen dissolved in $\mathrm{Nb}$. As the temperature is increased, the pressure in equilibrium with a given solution composition increases, though at $1200^{\circ} \mathrm{C}$ and $3000 \mathrm{ppm}$ the oxygen pressure is far below current analytical capabilities for detection of contaminants in inert gases.

The very low partial pressure of reactive gases in helium coolants and the difficulty in analys is have been indicated by DeVan. (13) For example, Charlot, et al., (14) report materials compatibility behavior in large high temperature helium loop operated at $300 \mathrm{psi}$ helium where the analytical systems routinely indicated less than $1 \mathrm{ppm}$ by volume contaminant. The principal impurity specie was hydrogen; oxygen was not detected. Exposure of corrosion specimens at $1150^{\circ} \mathrm{C}$ for times to 500 hours resulted in the following materials behavior: $\mathrm{Nb}$ and $\mathrm{Ta}$ were significantly contaminated by oxygen and carbon; Mo and $W$ were not affected; and $\mathrm{Ni}$ - and Co-base alloys were surface depleted of alloying constituents by evaporation.

Solution of the other equations in Table 2 for the contaminant pressures at terminal solubility indicate, as expected, that contamination of niobium by nitrogen or carbon (from a methane atmosphere, for example) will occur at very low contaminant overpressures. Although molybdenum shows some affinity for nitrogen, the high nitrogen pressure necessary to achieve equilibrium with $\mathrm{MON}_{2}$ precludes formation of this compound in a CTR helium coolant, al though some solution of nitrogen would be expected.

\subsection{DIFFUSION}

A summary of the diffusivity expressions for interstitials in $\mathrm{Nb}$ and Mo is shown in Table 3. These values are used later (in Section 5) to determine the rates of attaining equilibrium concentrations of contaminants in thin walled $\mathrm{Nb}$ and Mo reactor components.

\subsection{EFFECT OF ENVIRONMENT ON MECHANICAL PROPERTIES}

A wide range of alloy types are being considered for CTR applications. 


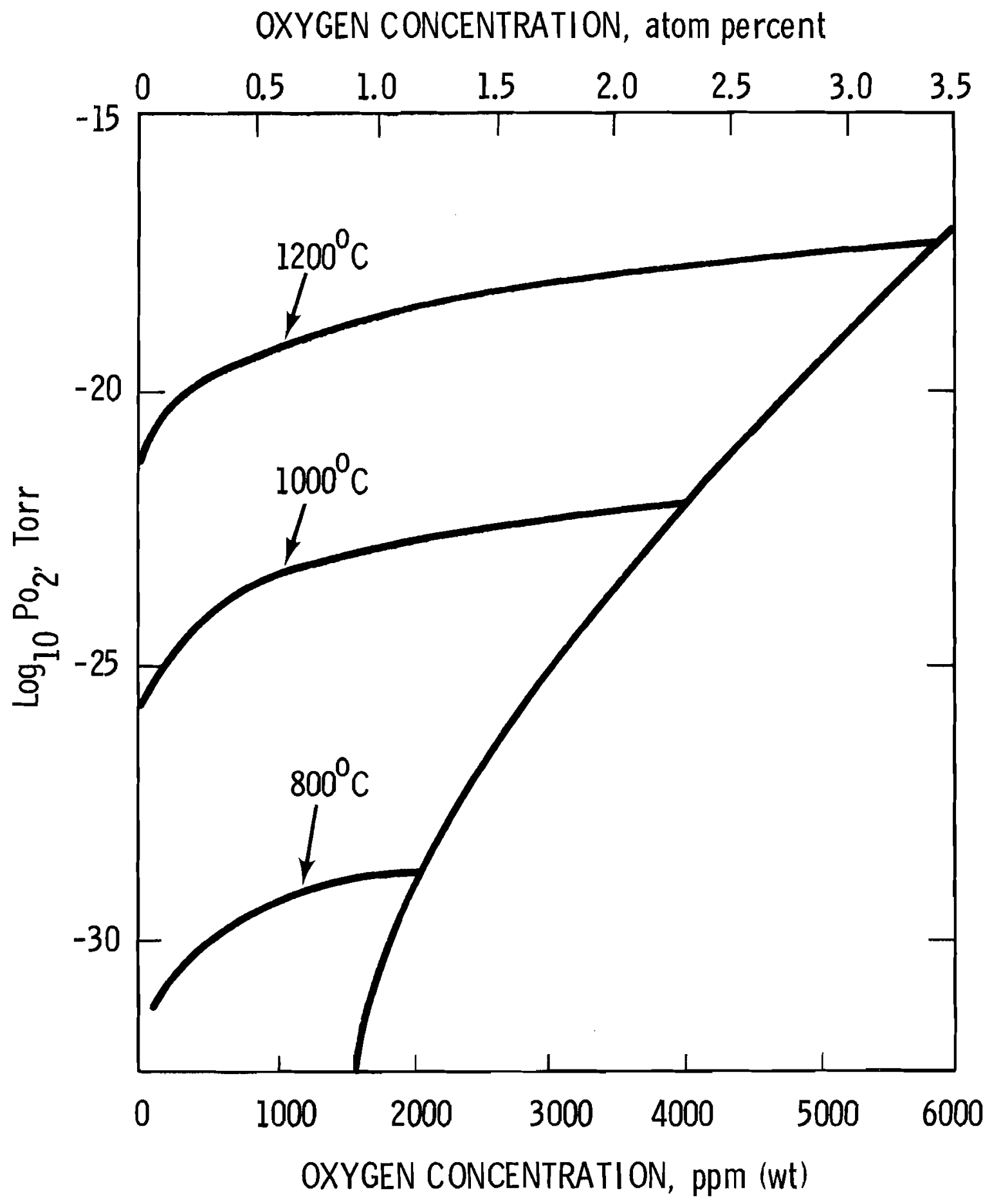

Figure 5

Solution and Terminal Solubility of Oxygen in Niobium 
TABLE 3

OXYGEN, CARBON AND INITROGEN DIFFUSION IN METALS

NIOBIUM

Interstitial

oxygen

Carbon

Nitrogen

$\frac{D, \mathrm{~cm}^{2} / \mathrm{sec}}{0.0041 \exp (-25,000 / R T)}$
$0.0147 \exp (-27,600 / R T)$
$0.014 \exp (-26,600 / R T)$

$0.0055 \exp (-33,200 / R T)$

$0.0100 \exp (-33,920 / R T)$

$0.033 \exp (-37,900 / R T)$

$0.0081 \exp (-34,800 / R T)$

$0.061 \exp (-38,800 / R T)$

$0.098 \exp (-38,600 / R T)$
$0.0023 \exp (-24,900 / R T)$

Temp.,${ }^{\circ} \mathrm{C}$
$600-1200$
$60-150$
$140-250$
$130-2430$
$930-1800$
$140-250$
$800-1600$
$900-1300$

\section{MOL YBDENUM}

Oxygen
Carbon

Nitrogen

$$
\begin{array}{ll}
0.03 \exp (-31,000 / R T) & 200 \\
0.00028 \exp (-166,500 / R T) & 100-400 \\
0.034 \exp (-41,000 / R T) & 178-1970
\end{array}
$$

$\begin{array}{lll}\mathrm{D}_{\mathrm{O}} & \exp & (-55,000 / \mathrm{RT}) \\ 0.0043 \exp & (-26,000 / \mathrm{RT})\end{array}$

$0.0023 \exp (-33,000 / R T)$
$1300-2000$

$800-2200$
Method

oxygen Gradient

Internal Friction

Internal Friction

Internal Friction

Electrotransport

Carbon 14 Tracer

Internal Friction

Nitrogen Gradient

Internal Friction

Nitrogen Gradient
Reference

15

16

17

17

18

19

17

20

16

21

Internal Friction

22

Internal Friction

23

Carbon Gradient

24

Nitrogen Gradient

Nitrogen Permeation

25

26

27 
These materials have markedly different reactions with and response to reactive gases in the environment. To define acceptable corrosion of, or contaminants in, a given alloy, it is necessary to evaluate the effects of a range of corrosion or contaminant levels on each alloy, then decide at what level the alloy becomes unsuitable in the environment for a given application. The effects of bulk metal corrosion and interstitial contaminants on the mechanical properties of stainless steels, niobium- and molybdenum-base alloys are summarized in this section.

\subsection{STAINLESS STEELS}

Most of the available data concerning the effect of environment on the high-temperature mechanical properties of stainless steels consists of creep and creep-rupture studies. Analysis of the data is not straightforward because the results obtained depend in an intricate manner on temperature, stress 1evel, reactive gas(es) present, steel composition, specimen geometry, and specimen pretreatment.

Kirschler and Andrews (28) determined the creep, stress-rupture, tensile, impact, and fatigue properties of Type 316 SS in air, helium, and sodium at $649^{\circ} \mathrm{C}$. Averaged yield strengths for all environments were similar, showing less than a 6 percent variation. The creep rates in helium and sodium were slightly higher than in air. The sample stresses required to produce 1 percent creep in helium and sodium in 10,000 hours were within 15 percent of the corresponding stress in air. The stress-rupture tests, to 4000 hours maximum time, showed no significant difference in rupture strength in any of the three environments. In the cyclic strain tests, the samples fatigued in air withstood the least cycles before failing and the samples in helium the most. At 1 percent cyclic strain, the samples in air failed in 21500 cycles; the samples tested in in helium withstood 240,000 cycles. The fatigue test yielded the only test results sensitive to environment.

LeMay, Truss, and Sethi ${ }^{(29)}$ determined the creep properties of Type 347 SS over the temperature range $604^{\circ} \mathrm{C}-791^{\circ} \mathrm{C}$ in air, nitrogen, argon (no purity noted) and vacuum $\left(5 \times 10^{-6}\right.$ Torr $)$. They found the rupture 1 ife to be lower in air than in argon or vacuum over the entire temperature range; the elongation at fracture was higher in air than in the other environments in every test, and was least in nitrogen and argon; analysis of minimum creep creep rates and reductions in area yielded no clear pattern. The tests in nitrogen were "inconclusive" but "no evidence for nitrogen strengthening could be found." The lowest elongation-at-fracture reported was 13 percent, 
and the lowest reduction-in-area 16 percent; both of these minimums came from tests in the argon environment.

McCoy ${ }^{(30)}$ studied the creep-rupture behavior of Type 304 SS in Ar, C0, $\mathrm{CO}_{2}, \mathrm{H}_{2}, \mathrm{~N}_{2}, \mathrm{O}_{2}$, and air at temperatures of $816^{\circ} \mathrm{C}$ and $927^{\circ} \mathrm{C}$. The environments listed in order of a decreasing strengthening effect at $816^{\circ} \mathrm{C}$ and 3400 psi are CO (1owest strain rate), $\mathrm{CO}_{2}, \mathrm{~N}_{2}$, air, $\mathrm{Ar}, \mathrm{H}_{2}$, and $\mathrm{O}_{2}$ (highest strain rate). The results are similar at $927^{\circ} \mathrm{C}$ and 1200 psi, except that $\mathrm{Ar}$ or $\mathrm{H}_{2}$ environments yielded higher strain rates than an $\mathrm{O}_{2}$ environment. McCoy pursued the effect of $\mathrm{O}_{2}$ pressure on creep rate by exposing creep specimens to $\mathrm{Ar}-\mathrm{O}_{2}$ mixtures at 1 atm total pressure at $816^{\circ} \mathrm{C}$. He found a maximum creep rupture 1 ife and a minimum creep rate at $\sim 10 \mathrm{ppm} 0_{2}$ in $\mathrm{Ar}$, and that the surface crack density increased with oxygen concentration. The oxygen partial pressure effects were considered "inexplicable."

Exposure of the stainless steel specimens to the $\mathrm{CO}-\mathrm{CO}_{2}$ environments resulted in carburization of the specimens. The increased creep strength obtained in these environments may be explained on the basis of dispersionhardening. The specimen in a $\mathrm{CO}$ environment showed a greater creep strength and also a higher carbon content than the specimen exposed to a $\mathrm{CO}_{2}$ environment. A signficant loss of rupture ductility is associated with increasing carbon content.

A dispersion-hardening mechanism is also invoked for the improvement of creep strength by nitrogen. Nitrogen is thought to strengthen the specimen through a hardening reaction near the sample surface.

McCoy concludes that creep data obtained in pure Ar are generally conservative for design purposes.

The unusual effect of oxygen on the creep strength of stainless steel reported by McCoy (30) was the subject of a further, more detailed study by Rodriguez ${ }^{(31)}$, who exposed creep specimens of Type 304 SS to Ar- $0_{2}$ mixtures at $815^{\circ} \mathrm{C}$ and $927^{\circ} \mathrm{C}$. At concentrations of $\mathrm{O}_{2}$ in the range 0 to $70 \mathrm{ppm}$, the creep rate decreases with increasing oxygen content at $815^{\circ} \mathrm{C}$ and 3400 psi stress. For oxygen concentrations between 70 and $250 \mathrm{ppm}$, the rate increases to a maximum value. The creep rate decreases at oxygen contents above $\sim 250 \mathrm{ppm}$, with the creep rate in pure $0_{2}$ approximating the $10 \mathrm{w}$ rate found at $\sim 70 \mathrm{ppm}$. The effect of oxygen on rupture ductility could not be determined, as too few tests were carried to rupture. 
At $927^{\circ} \mathrm{C}$ and 2000 psi stress, the data follow the same trend. The $927^{\circ} \mathrm{C}$ tests were carried to rupture but no significant influence of gas phase $\mathrm{O}_{2}$ content on rupture ductility was found. Rodriguez explains the oxygenpressure dependence of creep rate on the basis of the properties of the oxide surface scale formed in the various environments, i.e., a hard, tenacious scale will yield a higher creep strength than a weak, easily spalled oxide layer. Metallographic analys is showed no evidence of internal oxidation, and oxygen analyses showed no increase of oxygen in the bulk samples with increasing oxygen level in the environment. The specimen surface crack densities were found to increase with oxygen concentration in the environment, as reported by McCoy. The average crack depth attained a maximum value at $2250 \mathrm{ppm}$ oxygen, i.e., the level corresponding to maximum creep rate.

Wood, Farrow, and Burke ${ }^{(32)}$ studied the effect of air and helium at two impurity levels on the creep and rupture behavior of $316 \mathrm{SS}$ at $800^{\circ} \mathrm{C}$. Their experiments were directed at high temperature gas-cooled reactor technology, and this objective is reflected in the helium impurity levels: "nominally pure," a maximum total impurity level of $21000 \mathrm{ppm}^{\star}$ (1)argely $\mathrm{H}_{2}, \mathrm{CO}, \mathrm{H}_{2} \mathrm{O}$, and $\mathrm{N}_{2}$ ), and "nominally impure," a nominal composition of $1000 \mathrm{ppm} \mathrm{H}_{2}, 1000 \mathrm{ppm} \mathrm{C} 0$, and $100 \mathrm{ppm} \mathrm{H}_{2} \mathrm{O}$. The rupture times were found to be shorter and creep rates faster in both helium environments than in air. Averaging of the scattered data points yields a factor of four lower creep rate in air than in the helium environments, and a factor of three increase in rupture time in air over the helium environments. Metallographic examinations of failed specimens revealed a pronounced difference in oxidation between the specimens tested in air and specimens tested in helium. Specimens tested in air showed thick, relatively uniform scales, while those tested in helium showed non-uniform oxide layers, grain boundary oxide penetration, and generally selective attack.

Cook, et al., (33) cite some preliminary results for 316 SS creep tested

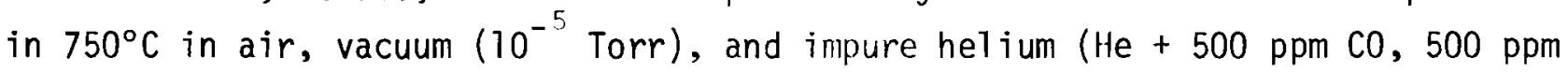
$\mathrm{H}_{2}$, and $50 \mathrm{ppm} \mathrm{H}_{2} \mathrm{O}$ at $10 \mathrm{psig}$ ). The creep rate in the impure helium was substantially higher (about a factor of two) than the creep rates in the air and vacuum environments. The higher rate is apparently caused by selective oxidation of the alloy in the impure helium, with sub-surface penetration of the reactive

In gas mixtures, "ppm" is generally defined as ppm by volume. For contaminants in metals, ppm by weight is the conmon usage. 
environment and depletion of alloying elements near grain boundaries. These findings are consistent with those of Wood, et al. (32)

Weinberg and Scoffin ${ }^{(34)}$ exposed tensile and impact-tensile specimens of Types $321 \mathrm{H}, 347,304$ and 403 stainless steels and Inconel to impure helium at $650^{\circ} \mathrm{C}$ and $760^{\circ} \mathrm{C}$ for times to 3000 hours. Two helium impurity levels were used: 200-300 ppm CO with 200-300 ppm H $3000 \mathrm{ppm} \mathrm{H}$. $0 x i d a t i o n$ rather than carburization appeared to be the major corrosion processes, although both carburization and decarburization were observed. None of the materials studied exhibited a large change in mechanical properties after an exposure at $650^{\circ} \mathrm{C}$, based on room temperature tensile and tensile-impact tests. After the $760^{\circ} \mathrm{C}$ exposures, only moderate changes in mechanical properties were observed for all materials except Type $321 \mathrm{H}$ stainless steel, which exhibited a large decrease in ductility after 1500 hours in the higher impurity environment. In general control specimens encapsulated in vacuo and held at the test temperatures were affected as greatly as the specimens exposed to the impure helium environments.

Smith, Shahinian, and Achter ${ }^{(35)}$ measured fatigue crack growth rates in Type $316 \mathrm{SS}$ at $500^{\circ} \mathrm{C}$ and $800^{\circ} \mathrm{C}$ as a function of oxygen pressure. Crack growth rates showed a sharp increase with oxygen pressure in an intermediate pressure range $\left(10^{-3}\right.$ to 1.0 Torr), but little or no change at pressures outside this range. At $500^{\circ} \mathrm{C}$, a 1 Torr $\mathrm{O}_{2}$ pressure reduced the fatigue 1 ife by a factor of 2100 compared to that in vacuum; at $800^{\circ} \mathrm{C}$ the effect was somewhat smaller. A model in which the rate of fresh metal surface production equals the rate of surface coverage by gas molecule adsorption explains the $500^{\circ} \mathrm{C}$ results, but at $800^{\circ} \mathrm{C}$ the model does not fit the experimental data. The authors note that oxidation strengthening, leading to increased fatigue resistance, can take place at higher temperatures. Smith and Shahinian (36) found at $500^{\circ} \mathrm{C}$ and $800^{\circ} \mathrm{C}$ that the rate of strain hardening of $316 \mathrm{SS}$ during cyclic straining prior to crack initiation is dependent on oxygen pressure, with pressures as $10 \mathrm{w}$ as $5 \times 10^{-4}$ Torr causing hardening at $500^{\circ} \mathrm{C}$. A pressure of $10^{-3}$ Torr initiated hardening at $800^{\circ} \mathrm{C}$.

The foregoing data compilation on compatibility of stainless steel with a variety of gases has not included a discussion of the damage which can be caused by hydrocarbons such as methane, common lubricants, diffusion pump oil, etc. Clean stainless steel surfaces at high temperatures can react rapidly with such carbonaceous materials causing gross carburization and 
embrittlement, due to the high diffusion rates of carbon in the bulk metal and the stability of chromium-rich carbides. "Green rot" is a common name applied to carburized and subsequently oxidized chromium-nickel alloys. While this type of attack may be considered generally beyond that expected from lightly contaminated helium, there is a possibility that it will occur in the event of an oil leak into the system or some other unexpected ingress of carbonaceous material.

\subsection{REFRACTORY METALS}

\subsubsection{Nb-0xygen}

Sheeley (37) determined the tensile properties of niobium contaminated with 200 and $1200 \mathrm{ppm}$ oxygen over the temperature range $22^{\circ} \mathrm{C}-1200^{\circ} \mathrm{C}$, and found no significant effect of these oxygen levels on ductility. Appreciable strengthening of the high-oxygen material, ascribed to dynamic strain-aging, was found in the temperature range $300^{\circ} \mathrm{C}-500^{\circ} \mathrm{C}$. McCoy and Douglas, (38) on the bas is of bend tests performed at room temperatures, found that oxygen strengthens niobium without seriously reducing. its room temperature ductility until oxygen levels of the order of $3000 \mathrm{ppm}$ are attained. Enrietto, (39) reports brittle fracture behavior in tensile tests of niobium specimens contaminated with $4300 \mathrm{ppm}$ oxygen at temperatures $<400^{\circ} \mathrm{C}$. At temperatures $>500^{\circ} \mathrm{C}$, the fracture was apparently ductile. Pronounced aging effects were observed in the $400^{\circ} \mathrm{C}-$ $600^{\circ} \mathrm{C}$ temperature range, for specimens containing 200 and 4300 ppm oxygen, producing marked increases in tensile strength properties. Hobson $(40)$ tensile tested niobium specimens at room temperature containing up to $930 \mathrm{ppm}$ combined $0_{2}, \mathrm{~N}_{2}, \mathrm{C}$, and $\mathrm{H}_{2}$. The specimens were aged for times to 100 hours at $927^{\circ} \mathrm{C}$ after a $1600^{\circ} \mathrm{C}$ anneal. He found that strength levels were "proportional to total impurity content," but that "only minor variations in strength and ductility were noted with [aging] time, indicating that little or no aging occurred in the unalloyed metal."

McCoy and Douglas ${ }^{(38)}$ creep tested niobium at $982^{\circ} \mathrm{C}$ and $1010^{\circ} \mathrm{C}$ in atmospheres of $\mathrm{Ar}$, $\mathrm{Ar}+\mathrm{air}$, wet $\mathrm{Ar}$, wet $\mathrm{H}_{2}$, and $\mathrm{H}_{2}$. They found that $\mathrm{O}_{2}$ increases the creep strength, but that $\mathrm{H}_{2}$, whether in the form of $\mathrm{H}_{2}$ or $\mathrm{H}_{2} \mathrm{O}$, greatly reduces the creep strength. 0xygen, present in the specimens at levels as high as $5100 \mathrm{ppm}$ (wet $\mathrm{H}_{2}$ environment, $982^{\circ} \mathrm{C}$ ), "did not reduce appreciably the rupture ductility of the specimens." Stoop and Shahinian $(41)$ determined the creep-rupture properties of niobium with oxygen additions up to $3500 \mathrm{ppm}$ in the temperature range $1038^{\circ} \mathrm{C}$ to $1427^{\circ} \mathrm{C}$ in a high-vacuum environment. They 
found that the rupture life generally increased and that the minimum creep rate decreased as the level of oxygen was raised. A1so, oxygen additions produced no deleterious effect on ductility.

Enrietto, et al ${ }^{(39)}$ fatigue-tested niobium specimens containing 10,200 , and $4300 \mathrm{ppm}$ oxygen at temperatures in the range $200^{\circ} \mathrm{C}-800^{\circ} \mathrm{C}$. Increasing the oxygen level increased the fatigue limit at al1 temperatures. The fatigue life for the samples containing 200 and 4300 ppm oxygen was a maximum at $400^{\circ} \mathrm{C}$.

\subsection{2 $\mathrm{Nb}-1 \mathrm{Zr}$-0xygen}

Lyon ${ }^{(42)}$ prepared specimens of $\mathrm{Nb}-1$ Zr with varying oxygen concentrations by exposing strips of the alloy to low partial pressures of oxygen at $927^{\circ} \mathrm{C}$. Appreciable room temperature ductility (13\% - 14\% elongation) remained in the contaminated alloy strips at oxygen levels of $5990 \mathrm{ppm}$. The strips were completeiy embrittled at oxygen levels $>8000$ ppm. Lyon ascribes the embrittlement to massive oxide precipitates in the grain boundaries, rather than to finely dispersed precipitate particles normally associated with age hardening. A strip of weld metal was found to be embrittled at an oxygen concentration of $4210 \mathrm{ppm}$, because of the large grain size of the material and the relatively small grain boundary area. Hobson $(40)$ notes the increase in hardness and tensile strength of $\mathrm{Nb}-1 \mathrm{Zr}$ after aging at $927^{\circ} \mathrm{C}$, and the dependence of these properties on the solution anneal temperature, aging time, and oxygen level (to $1200 \mathrm{ppm}$ ). However, no mention is made of the effect of the test parameters on ductility.

Bonesteel, et al ${ }^{(43)}$ internally oxidized specimens of $\mathrm{Nb}-1 \mathrm{Zr}$ by exposing them to a dynamic vacuum of $10^{-5}$ Torr at $800^{\circ} \mathrm{C}$ and $900^{\circ} \mathrm{C}$. The specimens were then creep tested at $1200^{\circ} \mathrm{C}$. The data show an improved creep strength of the contaminated material compared to non-oxidized material. Before creep testing a high density of coherent precipitate particles $<100 \AA$ in size were observed. After creep testing only large non-coherent precipitates of monoclinic $\mathrm{ZrO}_{2}$ were found.

Roche ${ }^{(44)}$ exposed cantilevered Nb-0.6 $\mathrm{Zr}$ specimens to varying gas pressures in the range $10^{-7}$ to $10^{-5}$ Torr for periods up to 504 hours at $1000^{\circ} \mathrm{C}$ and determined the specimen deflection rates as a function of system pressure. The specimens were loaded to an outer fiber stress of 12,500 psi. It was determined that the alloy could be weakened or strengthened by 
interstitial contamination, depending on the rate at which the interstitials were added, the interstitial solubility, and the instantaneous interstitial concentration. Pre-test contamination proved effective in strengthening the material during the early stages of the creep test. The alloy is strengthened by precipitation of dispersed phases, such as $\mathrm{ZrO}_{2}$ and/or niobium carbides and nitrides, and weakened by NbO precipitation. 0xygen concentrations as high as $19,700 \mathrm{ppm}$ were attained during the tests.

\subsubsection{Nb-Nitrogen}

McCoy and Douglas ${ }^{(38)}$ determined the effect of nitrogen on the room temperature bend properties of $\mathrm{Nb}$. Nitrogen was found to exert a profound strengthening effect with concentrations of the order of $1000 \mathrm{ppm}$ seriously embrittling the material. The effect of nitrogen on tensile properties was also determined. Concentrations of $\sim 2000 \mathrm{ppm}$ nitrogen doubled the proportional limit at room temperature, but reduced the ductility to essentially zero. Tensile specimens charged with nitrogen in the range 2000 - 3000 ppm and tested at $982^{\circ} \mathrm{C}$ exhibited strains at rupture between 9.5 and 18.0 percent. Surface cracking was evident in these specimens. Stoop and Shahinian ${ }^{(45)}$ tensile tested niobium specimens containing nitrogen at room temperature and found that nitrogen concentrations up to $2400 \mathrm{ppm}$ caused no appreciable loss of ductility. The minimum elongation at fracture was 27 percent. At $3700 \mathrm{ppm}$ the elongation dropped to $\sim$ percent. The embrittlement was attributed to massive nitrides in the grain boundaries. When specimens were rapidly cooled from the homogenization treatment temperature $\left(1482^{\circ} \mathrm{C}\right)$ to avoid massive nitride formation, the elongation increased to 7 percent. The more severe embrittlement reported by McCoy and Douglas ${ }^{(38)}$ appears to be due to the lack of an adequate homogenization treatment following the nitrogen addition. Also, the tensile and bend specimens of McCoy and Douglas contained appreciable quantities of oxygen $(300-800 \mathrm{ppm})$ in addition to the nitrogen.

Stoop and Shahinian $(45)$ found no influence of nitrogen to $4600 \mathrm{ppm}$ on ductility at elevated temperatures $\left(1038^{\circ} \mathrm{C}\right)$; the elongation-atfracture values for both tension and creep-rupture specimens were above 39 percent in a11 cases.

Creep resistance and rupture 1 ife are improved by nitrogen in solid solution at $927^{\circ} \mathrm{C}$ to $1038^{\circ} \mathrm{C}$, but at higher temperatures, to $1427^{\circ} \mathrm{C}$, they are not influenced by it. Nitrogen concentrations high enough to 
produce two-phase microstructures will improve creep resistance and rupture 1 ife at al1 test temperatures. (45)

\subsubsection{Molybdenum A110ys - 0xygen}

Liu and Inouye ${ }^{(46)}$ determined the tensile properties of TZM (Mo-0.5\% Ti-0.08\% Zr-0.03 C) specimens 0.020 inch thick after exposures at $825^{\circ} \mathrm{C}$ and $1000^{\circ} \mathrm{C}$ to $10 \mathrm{w}$ pressure $\mathrm{O}_{2}, \mathrm{CO}$, and $\mathrm{H}_{2} \mathrm{O}$. The specimens exposed to $\mathrm{O}_{2}$ at $1 \times 10^{-5}$ Torr for 2000 hours at $825^{\circ} \mathrm{C}$ showed a slight decrease in room temperature elongation and a small increase in strength when tensile tested at room temperature. However, room temperature ductility decreased rapidly with exposure time to $1 \times 10^{-5}$ Torr $0_{2}$ at $1000^{\circ} \mathrm{C}$, becoming ni1 at times $<200$ hours. 0xygen analyses of the specimens indicated complete room temperature embrittlement at oxygen levels of $\backsim 300 \mathrm{ppm}$. The oxygen was not uniformly distributed throughout these specimens, so that the $300 \mathrm{ppm}$ value cited can be considered an average value only, and the embrittlement found must be considered dependent on specimen geometry. This embrittlement was due to the internal oxidation of the $\mathrm{Ti}$ and $\mathrm{Zr}$ alloy constituents. Testing the material at $1316^{\circ} \mathrm{C}$ does not improve the ducti1ity, indicating absence of a tensile elongation transition temperature for this alloy.

\subsubsection{Molybdenum A1loys - Nitrogen}

Mukherjee and Martin (47) carried out 100-hour creep tests at temperatures between $950^{\circ} \mathrm{C}$ and $1260^{\circ} \mathrm{C}$ on $\mathrm{Mo}-0.49 \% \mathrm{Ti}, \mathrm{Mo}-0.98 \% \mathrm{Ti}$, and Mo-1.5\% $\mathrm{Zr}$ specimens that were nitrided in $\mathrm{NH}_{3}$ at $1500^{\circ} \mathrm{C}$. The nitrided Mo-Ti alloy specimens showed longer creep lives and lower creep rates at the same stress and temperature than un-nitrided specimens. The interpretation of the test results was not so clear for the Mo-Zr alloy.

Enhanced intergranular cracking was observed in the nitrided specimens. The nitrogen concentrations in the samples were not reported.

\subsection{CONTAMINANT/EIVIRONMENT CRITERIA}

Before the long-term compatibility of an environment with a given metal can be evaluated, the acceptable limits of contamination must be estimated through a knowledge of the effect of contaminants on the mechanical properties of the metal, taking into account the kinetics of the contamination reaction(s). For stainless steels in most reactive atmospheres, the greatest part of the contaminants will be found near the metal surface, especially if the environment 
is even slightly oxidizing. The mechanical properties of contaminated stainless steel are generally not expressed in terms of contaminant level in the metal, e.g., "ppm oxygen," but are generally expressed in terms of the composition of the environment the steel is, or was, exposed to. For reactive metals with large interstitial solubilities, such as $\mathrm{Nb}$ and $\mathrm{V}$, the mechanical properties may be put, at least approximately, in terms of contaminant level, providing the base data was obtained on homogenized specimens produced under reasonably relevant conditions. Care must be taken in correlating expected mechanical properties with contaminant levels when the materials being considered are alloys, because the mechanical properties can vary greatly depending on the conditions of contaminant charging. For example, a material containing an alloying element having a higher affinity for the contaminant species than the base metal ( $\mathrm{Hf}-1 \mathrm{Zr}$, Mo-TZM, or Ta-8W-2Hf in the presence of $\mathrm{O}_{2}$ ) can exhibit markedly different properties depending on the temperature and the rate of contaminant absorption. This is because the exposure conditions dictate the size and distribution of second-phase particles and produce varying degrees of dispersion hardening, hence embrittlement. Liu, et al., (48) found that specimens of a Ta-8W-2Hf alloy could tolerate oxygen levels as high as 4200 ppm before completely losing ductility, if the alloys were annealed at $1700^{\circ} \mathrm{C}$ after a $1000^{\circ} \mathrm{C}$ oxygen charging operation. However, if there was no annealing treatment, the specimens were completely embrittled at $800 \mathrm{ppm}$ oxygen.

Data of this type are not available on all alloys being considered for CTR applications. It is therefore necessary to exercise caution in using the incomplete data that is available and to recognize that unforeseen phenomena may profoundly influence mechanical properties. The data summary presented in this section is, for this reason, intended to serve only as a preliminary guide in selecting materials and defining required CTR operating conditions.

\subsection{STAINLESS STEELS}

Assuming that the mechanical property basis for application of austenitic stainless steels to a CTR structure consists of data obtained in high purity (high vacuum) environments, the following property changes may be expected when stainless steels are exposed to reactive gases in a helium coolant stream in the temperature range $600^{\circ} \mathrm{C}-800^{\circ} \mathrm{C}$ :

- Low concentrations of $\mathrm{O}_{2}$ and $\mathrm{N}_{2}$ will most likely result in an increase in creep strength. 
- Presence of reducing gases, such as $\mathrm{H}_{2}$ and $\mathrm{CO}$, can cause a decrease in creep strength, if the oxidizing power of the gas is such that selective oxidation of the steel constituents occurs.

- Hydrocarbon impurities tend to carburize stainless steels, with an initial increase in creep strength and ultimate embrittlement.

- Presence of $\mathrm{CO}$ and $\mathrm{CO}_{2}$ wi11 generally carburize the material, causing an increase in creep strength and eventual embrittlement. If the carbon oxides are present at very low concentrations, the carburizing reactions will be very slow.*

- Reactive constituents in the helium stream are likely to have a deleterious effect on steel fatigue 1 ife, especially if the fatigue cycling is fixed-strain rather than fixed-load. Fixedstrain cycling tends to limit the benefit of contaminant induced hardening.

- When stainless steel is oxidized and then exposed in an inert environment, the oxide tends to eventually lose adherence and spall away. This can lead to the presence of particulate materials in the gas stream.

- Stainless steels are known to evaporate in inert environments. The phenomenon has been observed and measured in vacuo at temperatures as 1 ow as $760^{\circ} \mathrm{C} .{ }^{(49)}$ An inert gas overpressure does reduce the magnitude of the evaporation rate. (14) Metal vapors constitute a type of impurity to be expected in a "clean" system, and should be taken into account when any process is considered in which the transfer of structural material from one portion of the system to another could be important, e.g., the transport of radioactive materials or the plugging of filters or ports in a cool region.

In inert gas cooled fission reactors, the large graphite inventory is the primary source for carbon containing impurities. The general range of impurity partial pressures of interest are ${ }_{64} 5$ to $15 \mu$ atm for $\mathrm{CO}_{0} 0.1$ to $25 \mu \mathrm{atm}$ for $\mathrm{CH}_{4}$, and 0.5 to $5 \mu \mathrm{atm}$ for $\mathrm{CO}_{2} \cdot(64)\left(1 \mu \mathrm{atm}=7.6 \times 10^{-4}\right.$ Torr $)$ 
In regard to preferred steel composition, there are experimental data indicating that $\mathrm{Nb}$-stabilized steels such as Type 347 are superior to $\mathrm{Ti}$ stabilized steels, such as Type 321 , in contaminated helium environments. $(50,51)$

It should be noted that stainless steels and other iron-base alloys are being extensively used in high-temperature gas-cooled fission reactors. The alloys are generally performing well; Dragon Project and AVR experience indicates essentially no compatibility problems with structural materials in normal (contaminated) helium service. $(52,53)$

\subsection{REFRACTORY METALS}

If the assumption is made that a refractory metal equilibrates with the gas stream during its service life, then its mechanical properties can be approximately defined by the amount of contaminant it has picked up. Unlike the stainless steels, contaminants in refractory metals are generally not restricted to surface regions as protective, insoluble surface scales.

The levels of permissible contaminants (Table 4) have been estimated for $\mathrm{Nb}$ - and Mo-base alloys primarily on the basis of nil room temperature ductility, as the materials appeared to be most sensitive to this criterion. The data are limited and must be considered only approximate. The research work given the most weight in selecting each value is also referenced in the table.

\section{TABLE 4}

\section{PERMISSIBLE CONTAMINANT LEVELS}

Contaminant Levels, weight ppm

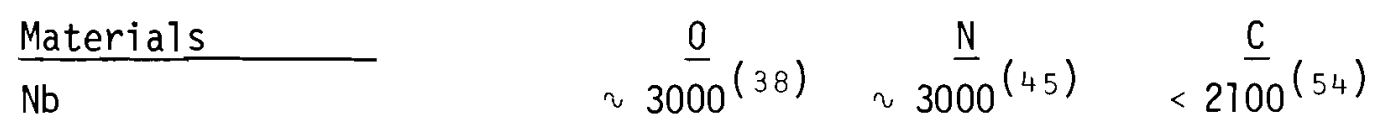

$\begin{array}{ll}\text { Nb-1 Zr } & \\ \text { Wrought } & \sim 8000^{(42)+} \\ \text { Weld Metal } & <4000^{(42)+} \\ \text { Mo-TZM } & \sim 300^{(46)}\end{array}$

+Values could be lower under conditions of low temperature contaminant absorption; i.e., temperatures $<927^{\circ} \mathrm{C}$.

We do not consider hydrogen to be a particularly harmful contaminant, if present in quantities of only a few ppm in the helium stream, as the solubility

\footnotetext{
Arbeitsgemeinschaft Versuchsreaktor AVR GmbH., Dusseldorf.
} 
of hydrogen in the alloys considered is extremely low at temperatures of $\sim 1000^{\circ} \mathrm{C}$ in equilibrium with such partial pressures. If "isotope swamping" techniques, i.e., purposeful additions of hydrogen isotopes to sweep trace quantities of tritium from the system, are used as an aid to tritium recovery, and if substantial hydrogen pressures will persist in the system to low temperatures, i.e., $<300^{\circ} \mathrm{C}$, then this position on the potential harmful effects due to hydrogen would have to re-examined, especially in the case of Nb-base al1oys.

Chandler and Walter ${ }^{(55)}$ have published a comprehensive review of the effects of hydrogen on refractory metals.

\subsection{CONTAMINANT CONTROL}

\subsection{STAINLESS STEELS}

Stainless steels, exposed to impure helium in the temperature range $600^{\circ} \mathrm{C}-650^{\circ} \mathrm{C}$, and refractory metals, operating at still higher temperatures, present two widely different compatibility situations. Stainless steels are protected from a reactive gas environment by virtue of a protective oxide film and concomitant slow surface reactions, so that the thermodynamic equilibration of a stainless steel with a reactive gas environment is not anticipated. Providing that reasonable care is taken in purifying the helium coolant of hydrocarbons and providing that the contaminants present do not react selectively with the steel constituents, stainless steels are generally considered to be compatible with helium coolants. This generalization is especially credible in the lower regions of the temperature range noted.

\subsection{REFRACTORY METALS}

Refractory metals are basically incompatible with reactive gas contaminants in a helium coolant, as protective films do not tend to form. The attainment of thermodynamic equilibrium of the metal with the reactive gas becomes a distinct possibility. This is generally undesirable in the case of $\mathrm{Nb}-0$ reactions. Figure 5 shows that a pressure of $10^{-22}$ Torr $\mathrm{O}_{2}$ is in equilibrium with $3000 \mathrm{ppm}$ oxygen in $\mathrm{Nb}$, a level sufficient to embrittle the material. Similar thermodynamics prevail for the less reactive Mo, if it is alloyed with a reactive metal, such as $T i$, as in the TZM alloy. Pure Mo would be expected to resist embrittlement better than such alloys, al though the 
oxidizing potential of the impurities present should not exceed that equivalent of $10^{-10}$ Torr $\mathrm{O}_{2}$, the equilibrium pressure for $\mathrm{MoO}_{3}$ formation, if $10 \mathrm{ss}$ or transport of the Mo is to be completely avoided. If $\mathrm{H}_{2}$ additions to the helium stream can be tolerated, then the Mo compatibility situation markedly improves, as a $\mathrm{H}_{2} / \mathrm{H}_{2} \mathrm{O}$ ratio of $1 / 10$ will prevent $\mathrm{MoO}_{3}$ formation, and a ratio equal to 1 will prevent $\mathrm{MoO}_{2}$ from forming. Serious consideration should be given to hydrogen isotope additions if Mo is used in such applications. For the present discussion it will be assumed that alloys are reactive and that thermodynamics favor contaminant absorption and alloy ernbrittlement.

There are three possible constraints on the contamination of bulk refractory metals in the presence of very low partial pressures of reactive gases at high operating temperatures:

- Slow surface reaction(s)

- Slow bulk diffusion

- Limitation of contaminant availability.

Duplex or coated materials will not be considered in this analysis.

of the three constraints listed, the first two are materials-dependent, and only the last is system- and operation-dependent.

\subsubsection{Rate of Surface Reactions}

The rates of surface reactions of refractory metals in low pressure, high temperature reactive gases have been extensively investigated; see for exaniple References 56 - 59.

Studies on "sticking probability," i.e., the ratio of the number of atoms "sticking" to a metal surface to the total number of atom impingements, in low partial pressure contaminant gases, generally demonstrate rapid surface reaction kinetics.

Lyon (42) studied the "sticking probability" of $0_{2}$ molecules on clean surfaces of $\mathrm{Nb}-1 \mathrm{Zr}$ alloy, and found values as high as 0.65 at $927^{\circ} \mathrm{C}$ under high vacuum conditions. For $\mathrm{O}_{2}$ pressures in the range of $10^{-7}$ Torr, oxygen levels of $4000-9000 \mathrm{ppm}$ were obtained in $0.076 \mathrm{~cm}(0.030 \mathrm{in}$.) specimens in exposure times of 200 - 500 hours. Liu and Inouye ${ }^{(46)}$ reported serious embrittlement of Mo-Ti-Zr alloy (TZM) after a 207-hour exposure to $10^{-5}$ Torr oxygen pressures at $1000^{\circ} \mathrm{C}$, which produced an average oxygen content of $480 \mathrm{ppm}$ oxygen through 
$0.051 \mathrm{~cm}(0.020 \mathrm{in.})$ specimens. They conclude that at $825^{\circ} \mathrm{C}$ the rate-determining step in reactions of TZM with $\mathrm{O}_{2}, \mathrm{CO}$, and $\mathrm{H}_{2} \mathrm{O}$ is bulk diffusion, but at $1000^{\circ} \mathrm{C}$ oxygen availability (hence molecule chemisorption) at the surface becomes largely rate controlling.

If the high metal contamination rates reported to occur in $10^{-5}$ Torr $0_{2}$ (this is equivalent to $3 \times 10^{-4} \mathrm{ppm} 0_{2}$ in helium at 50 atm pressure) reflect the rate of surface reactions, we must conclude that both $\mathrm{Nb} 1 \mathrm{Zr}$ and Mo-TZM alloys react rapidly with trace contaminants, and slowness of a surface reaction cannot be relied upon to preserve such structures from gross contamination.

\subsubsection{Rate of Bulk Diffusion}

If the surface of a refractory metal is assumed to be in equilibrium with the contaminants in the helium gas stream, time will be required for the major part of the structure to become affected by the contaminant. This time period can be easily estimated in the case of pure metals from a knowledge of the individual contaminant diffusivities.

Assume that one side of a sheet of $\mathrm{Nb} 0.3 \mathrm{~cm}$ thick is in equilibrium with a low partial pressure of oxygen. Using the diffusivity data for oxygen in $\mathrm{Nb}$ (see Section 2.3) and the diffusion tables of Darken and Gurry $(60)$ it can be shown that the time required for the level of oxygen at the remote wal1 to attain $90 \%$ of the value of the continuously contaminated wall is approximately one week at $1000^{\circ} \mathrm{C}$. This is increased to $\sim 12$ weeks for nitrogen contamination. Although the sheet thickness value of $0.3 \mathrm{~cm}$ is arbitrary, it is obvious that bulk diffusion of contaminants will be fast on a CTR structural-lifetime time scale.

When reactive alloy constituents are present in the material, the diffusion calculations become more complex, since the alloying elements act as sinks for the diffusing species. The presence of internal sinks tend to impede inward contaminant migration while forming subscale precipitates. The depth of subscale formation may be estimated by the relation of Rhines, et al: (61)

$$
\frac{x^{2}}{t}=\frac{2 D_{0} C_{0}-1.68(0 / M) C_{m} D_{m}}{(0 / M) C_{m}+C_{0} / 3}
$$

where: $x=$ depth of subscale, $\mathrm{cm}$

$t=$ reaction time, sec. 


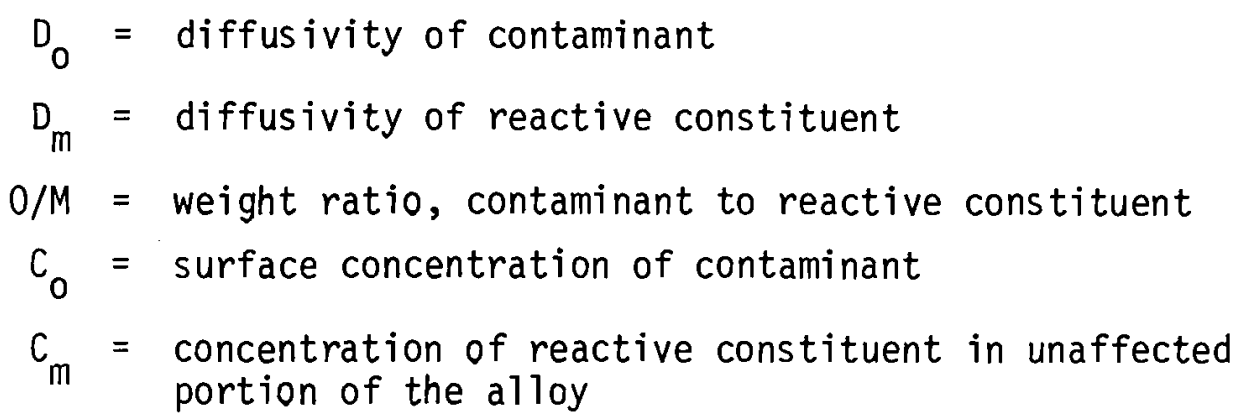

The relation assumes a concentration of contaminant of essentially zero in equilibrium with the compound formed and a level of reactive element of essentially zero in the subscale region.

Equation 6 was applied to the $\mathrm{Nb}-1 \mathrm{Zr}$ alloy, assuming a temperature of $1000^{\circ} \mathrm{C}$, an alloy thickness of $0.3 \mathrm{~cm}$, and various surface concentrations of oxygen. The time required for the subscale zone to completely penetrate the full $0.3 \mathrm{~cm}$ thickness is given below:

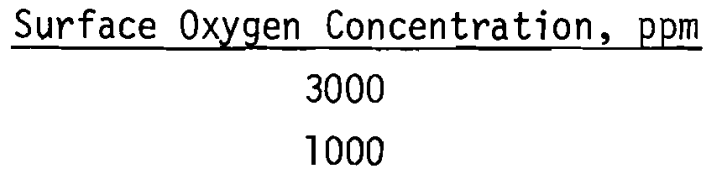

100

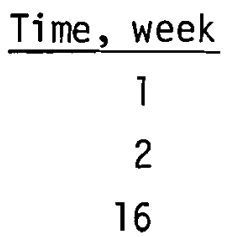

In the case of the TZM alloy, the time for $0.3 \mathrm{~cm}$ subscale movement would be far longer, as the terminal solubility of oxygen in Mo is only $\sim 16 \mathrm{ppm}$ at $1000^{\circ} \mathrm{C}$. This very low terminal solubility greatly restricts the slope of permissible oxygen concentration gradients. If it is assumed that the surface of the TZM is maintained at $16 \mathrm{ppm}$, then a time period of 2 years is required for complete subscale formation. Of course, serious mechanical property degradation would be expected before the end of this two-year period, because ful1 conversion of reactive constituent to subscale is not required before the material becomes embrittled.

The foregoing calculations illustrate that bulk diffusion of contaminants in refractory metals is not sufficiently slow to prevent their 'gross contamination' if contaminants are available for reaction.

\subsubsection{Limitation of Contaminant Availability}

Because the reaction between contaminants and refractory metals is rapid, it becomes necessary to assume that any contaminant finding its way into the system will react with and become distributed in the structural materials 
of the system. The problem becomes one of system design, fabrication, and operation with the objective of complete impurity control. The feasibility of such impurity control must obviously be assessed before construction of a refractory metal system is attempted.

It is important to first consider the potential sources of contaminant in a CTR system and analyze the relative importance of each:

- Impurities contained in the helium charge and makeup.

- Impurities adsorbed on the walls of the system.

- Impurity in-leakage via molecular flow.

- Impurity migration by surface diffusion along the surfaces of large pores.

- Impurities from component out-gassing.

- Viscous flow in-leakage from high-pressure secondary system.

The list of impurity sources disregards contamination on the "outside" of the helium-filled system. This is an extremely important area which must be carefully considered in any detailed overall analysis, but such an analysis is beyond the scope of the present work.

Each of the contaminant sources listed above will be analyzed individual $7 y$.

- Impurities contained in helium charae and makeup: Consider a CTR of Princeton reference design.(62) If all of the cooling tubes of the radiation shield wal1, the vacuum wall, the breeder blanket, and the divertor walls were constructed of $\mathrm{Nb}-1 \mathrm{Zr}$ instead of Nimonic PE-16, and if the same tubing dimensions were retained throughout, a mass of $245 \times 10^{4} \mathrm{Kg} \mathrm{of} \mathrm{Nb}-1 \mathrm{Zr}$ alloy would be present in the system. The shielding blanket tubing is not included as part of the Nb-1 $\mathrm{Zr}$ inventory, because of the relatively low temperatures in that region. All helium ducting and storage vessels are also excluded. The helium inventory is projected to be $2 \times 10^{5} \mathrm{~m}^{3}$ at STP, or $3.6 \times 10^{4} \mathrm{~kg}$. Using these approximations, we find that

$$
\frac{\text { Mass helium }}{\text { Mass of reactive metal }}=\frac{3.6 \times 10^{4}}{45 \times 10^{4}} \sim 0.1
$$


Since the weight of metal is 210 times the weight of helium, any impurity present in a helium charge would turn up in the metal at $21 / 10$ the concentration at which it was originally present in the helium. Thus, $10 \mathrm{ppm}$ by weight of $\mathrm{O}_{2}$ in the helium would produce only $\sim \mathrm{ppm}$ by weight of oxygen in the metal, if it were uniformly distributed. This type of reasoning indicates a large tolerance on the part of the structural materials for impurities present in a helium charge, as hundreds of complete charges of purified helium could be tolerated before the mechanical properties of the alloy became seriously affected by impurities from this source.

- Adsorbed impurities: A Nb-1 $\mathrm{Zr}$ alloy tube with a $0.3 \mathrm{~cm}$ thick wall can be considered to be $210^{22}$ atoms thick. If we conservatively assume that an adsorbed layer of impurity atoms 100 atoms thick forms 10,000 times (e.g., after opening the system to the atmosphere) and dissolves in the underlying metal after it forms each time, we have increased the contamination level of the substrate by

$$
\frac{1000 \times 10,000 \times 100}{10^{22}} \text { at } \% \text {, or } 10^{-13} \text { at } \% \text {. }
$$

If we assume that the adsorbed atoms are oxygen, we may multiply this value by 0.2 to convert to wt $\%$. It is obvious that adsorbed atoms cannot account for substantial increases in impurity concentration in the metal.

Impurity in-leakage via molecular flow: It is anticipated that the helium coolant will be pressurized to a level of the order of 50 atmospheres. Leakage will generally tend to be outward, rather than inward, unless the primary helium coolant is coupled to a higher pressure secondary system. Excluding the latter possibility, impurity gases will not be able to diffuse inward unless the leaks are extremely smal1, i.e., of a dimension somewhat less than the mean free path of helium at the temperature in question $\left(0.7 \times 10^{-6} \mathrm{~cm}\right.$ at $50 \mathrm{~atm}$ and $1000^{\circ} \mathrm{C} ; 0.3 \times 10^{-6} \mathrm{~cm}$ at $50 \mathrm{~atm}$ and $20^{\circ} \mathrm{C}$ ). If the leaks are larger than this, the outward viscous flow 
of helium will reduce the inward diffusion of gases to essentially zero. If we again use the Princeton reference design as our model: a tube wall thickness of $0.3 \mathrm{~cm}$; an air partial pressure differential of $1 \mathrm{~atm}$; leak dimensions $10^{-12} \mathrm{~cm}^{2} \times 0.3 \mathrm{~cm}$ long; and a time period of 5 years; and compute the number of leaks required to admit $5000 \mathrm{ppm}$ air into the helium ( $500 \mathrm{ppm}$ uniformly dissolved in the metal), we find $(61)$ that 4000 such leaks $/ \mathrm{cm}^{2}$ of tubing area would be required. It is extremely improbable that in-leakage by molecular flow represents a significant source of impurities.

- Impurity in-leakage via surface diffusion: The ingress of impurities takes place even in the case of large leaks, against steep pressure differentials, since it is possible for impurity atoms to diffuse inward along the surfaces or walls of the pores or fissures. An analysis of this phenomena has not been made; it is intuitively improbable that such diffusional processes could contribute the large masses of contaminant required to have a significant effect on the mechanical properties of large masses of reactive metal, without postulating incredible fissure wall areas to provide the required amount of diffusion pathway.

- Impurities from component outgassing: 0utgassing of contaminantladen components of a CTR coolant system represents a potentially serious source of contaminants. These components would include insulation, elastomer seals, gaskets, purification system beds, etc. It is difficult to predict impurity contributions from such sources, but the potential hazards must be recognized and such contaminant sources eliminated from a CTR design.

- In-leakage from a secondary system: Impurity in-leakage by viscous flow under a positive pressure differential from a secondary system containing a reactive (or highly contaminated) heat transfer medium must be considered intolerable, as sufficient impurity could enter the system in seconds (in the case of a high-pressure steam leak, for example) to totally destroy the primary system. 
In summary, if a primary system can be designed and fabricated to eliminate the significant sources of impurities listed in the foregoing section, the preservation of the reactive metal becomes dependent on operating procedure. The following points should be kept in mind in drawing up an operating procedure:

- Initial charge gas should be purified to the highest possible degree.

- The initial charge gas should be heated slowly, with the purification system operating. In this way adsorbed gases and component outgassing can be taken up by the purification system without severe contamination of the metal components.

- When the gas temperature is in the range of $200^{\circ} \mathrm{C}-400^{\circ} \mathrm{C}$, and further outgassing has become negligible, the purification system should be isolated. As the temperature is further increased the purification system cannot compete with the massive "getter bed" of the reactive metal primary system, and will eventually only contribute impurities to the system.

\subsection{CONCLUSIONS}

Stainless steels appear to be suitable materials for CTR applications in impure helium at temperatures to $650^{\circ} \mathrm{C}$, providing certain gas purity and alloy composition criteria are satisfied.

A refractory metal system can accommodate a certain amount of impurities before serious mechanical property degradation occurs. The amount of tolerable contaminant depends on the alloy, the contaminant, the temperature of contamination, and the rate at which contaminants are added. Some mechanical property data are available on contaminated refractory metals. These data resulted from a variety of programs, primarily aerospace-oriented. Before serious CTR design efforts are initiated, investigation of the effects of 1ong-term exposure of CTR candidate refractory metal alloys to high temperature prototypical helium coolant is essential. The investigations should emphasize materials corrosion and concomitant effects on short-term tensile properties, creep and creep-rupture strengths, fracture toughness, and resistance to mechanical and thermal fatigue.

In general, any steady-state source of contaminants must be eliminated from a CTR primary system, whether it be in-leakage, component outgassing, or inadequate purification systems. A CTR system can tolerate reasonable batch-wise additions of contaminants, especially if they become uniformly distributed. 
Such additions would occur, for example, in the case of a new helium charge.

The design, fabrication, and operation of a CTR utilizing reactive metal components constitutes an extremely demanding task. However, the possibility of success must not be discounted on thermodynamic bases alone. The real requirement is complete control of the mass of contaminants admitted to the system over its projected operating 1 ife.

\subsection{REFERENCES}

1. G.R. Hopkins, G. Melese-d'Hospital, "Direct Helium Cooling Cycle for a Fusion Reactor," B.N.E.S. Nuclear Fusion Reactor Conference at Culham Laboratory, September 1969, 522-535.

2. L.D. Hansborough, "Tritium Inventories and Leakage: A REview and Some Additional Considerations," Technology of Controlled Thermonuclear Fusion Experiments and the Engineering Aspects of Fusion Reactors, CONF-721111, 98. 1974.

3. R.G. Mi11s, "Princeton Reactor Studies Program," Ibid. 1.

4. R.W. Davison, "Blanket-Cooling Optimization for the Princeton Fusion Power Reactor," Ibid. 538.

5. S. Forster, K.W. Schneider, "Design Possibilities and Consequences for the Conventional Parts of Fusion Power Plants," Symposium of Fusion Technology, Aachen, September 1970.

6. K. Sako, M. Onta, Y. Seki, H. Yamato, T. Hiraoka, K. Tanaka, N. Asami, S. Mori, Conceptual Design of a Gas Cooled Takamak Reactor, JAERI-M 5502. 1974.

7. J.T.D. Mitche11, J.A. Booth, Wall Loading Limitation in a Helium Cooled Fusion Reactor Blanket, CLM-R 126, November 1973.

8. E. Fromm, "Thermodynamische Besdereibung Der Festen Losing von Kohlenstoff, Stick Stoff und Sauerstoff in Niob und Tantal," J. Less-Common Meta1s, 14, 113. 1968.

9. E. Fromn, H. Jehn, "Thermodynamics and Phase Relations in Refractory Metal Solid Solutions Containing Carbon, Nitrogen and Oxygen," Metallurgical Transactions, $5,1685.1972$

10. E. Fromm, "Gas-Metal Reactions of Refractory Metals at High Temperature in High Vacuum," J. Vacuum Science Technology, 7, 101. 1970.

11. H.L. Schick, Thermodynamics of Certain Refractory Compounds, Vol. II, Academic Press, New York. 1966.

12. 0. Kubaschewski, E.U. Evans, Metallurgical Thermochemistry, John Wiley and Sons, New York. 331-338. 1956. 
13. J.H. DeVan, "Compatibility," Fusion Reactor First Wall Materials, Edited by L. C. Ianniel10, WASH-1206, 25-31, Apri1 1972.

14. L.A. Charlot, R.E. Westerman, R.A. Thiede, Corrosion of Superalloys and Refractory Metals in High Temperature Flowing Helium, BNWL-SA-1137. 1967

15. R.I. Jaffee, W.D. KTopp, C.T. Sims, "High Temperature Oxidation and Contamination of Columbium," Trans. ASM, 51, 282. 1959.

16. C.Y. Ang, "Activation Energies and Diffusion Coefficients of Oxygen and Nitrogen in Niobium and Tantalum," Acta Met., 1, 123. 1953.

17. R.W. Powers, M.V. Doyle, "Diffusion of Interstitial Solutes in the Group V Transition Metals," ‥ Applied Physics, 30, 514. 1959.

18. F.A. Schmidt, O.N. Carlson, "Electrotransport of Carbon in Niobium and Tantalum," J. Less-Common Metals, 26, 247. 1972.

19. P. Son, M. Miyaka, T. Sano, "Diffusion of $C$ in Ta, Nb and V," abstracted in Diffusion Data, 3 , 420. 1969.

20. W.M. Albrecht, S.D. Goodes Reaction of Nitrogen with Niobium, BMI-1360. 1960.

21. T.0. Orqutani, E.M. Byque, "Diffusion of Nitrogen in Niobium With Special Reference to Temperature Dependence of the Activation Energy," Abstracted in Corrosion Abstracts, 12, 14. 1973.

22. Diffusion Data, 3, 147. 1969.

23. V.Y. Shcheldonogov, et al, Diffusion Data, 2, 136. 1968.

24. P.S. Rudman, "Solubility Limit and Diffusivity of Carbon in Molybdenum," Trans AIME, 239, 1949. 1967.

25. A. Ferro, "Theory of Diffusion Constants in Interstitial Solid Solution of BCC Metals," ‥ Applied Physics, 28, 895. 1957.

26. H. Jehn, E. Fromm, "Diffusion of Nitrogen in Mo and $W, " \underline{J}$. Less-Common Meta1s, 21, 336. 1970

27. R. Frauenfelder, "Permeation, Diffusion and Solution of Nitrogen in Tungsten and Molybdenum," $\mathrm{J}$. Chem. Physics, 38, 3966. 1968.

28. L.H. Kirschler, R.C. Andrews, "A Limited Comparison of the Mechanical Strength of Austenitic Steel in $1200^{\circ} \mathrm{F}$ Sodium, Air, and Helium," Trans ASIME, ․ of Basic Engineering, Paper No. 69-Met-F, 1969.

29. I. LeMay, K.J. Truss, P.S. Sethi, "Effect of Some Gaseous Environments on the Creep of a Stainless Stee1," ASME Paper 69-Met-3, 1969.

30. H.E. McCoy, "The Influence of Various Gaseous Environments on the CreepRupture Properties of Nuclear Materials Selected for High-Temperature Service," Proceedings of the Conference on Corrosion of Reactor Materials, Vo1. 1. Vienna: International Atomic Energy Agency, 263-296, 1962 
31. P. Rodriquez, High Temperature Creep Behavior of Type 304 Stainless Steel in Argon-0xygen Environment of Different Oxygen Partial Pressures, ORNL-TM-1124, May 5, 1965.

32. D.S. Wood, M. Farrow, W.T. Burke, "A Preliminary Study of the Effect of Helium Environment on the Creep and Rupture Behavior of Type 316 Stainless Steel and Incoloy 800," Effects of Environment on Material Properties in Nuclear Systems, British Nuclear Energy Society Conference on Corrosion, 213-228. 1971 .

33. R.H. Cook, J. Barford, G. Willoughly, Ibid. 234.

34. A.F. Weinberg, J.M. Scoffin, Exposure of Reactor Structural Materials to Impure Helium at Elevated Temperatures, GA-2998, March 1962.

35. H.H. Smith, P. Shahinian, M.R. Achter, "Fatigue Crack Growth Rates in Type 316 Stainless Steel at Elevated Temperature as a Function of 0xygen Pressure," Trans. AIME, Vol 245, 947-953. 1969.

36. H.H. Smith, P. Shahinian, "Effect of an Oxygen Atmosphere on Cyclic Hardening in Type 316 Stairless Steel," Metallurgical Transactions, Vol 1, 2007-2009. 1970.

37. W.F. Sheely, "Mechanical Properties of Niobium-0xygen A11oys," J. LessComrion Metals, Vol. 4, 487-495. 1962.

38. H.E. McCoy, D.A. Douglas, "Effect of Various Gaseous Contaminants on the Strength and Formability of Columbium," Columbium Metallurgy, Metallurgical Society Conferences, Vol 10, Edited by D.L. Douglas, F.W. Kungz, Interscience, 1961. 85-118.

39. J.F. Enrietto, "Mechanical Behavior of Columbium Containing Oxygen," Ibid. 503-521.

40. D.0. Hobson, "Aging Phenomena in Columbium-Base Alloys," High Temperature Materials II, Meta1lurgical Society Conferences, Vol. 18, Edited by G.M. Ault, W.F. Barclay, H.P. Munzer, Interscience, 19 $\overline{63}$. 325-334.

41. J. Stoop, P. Shahinian, "Effect of Oxygen on Creep-Rupture of Niobium," NRL-6095, July 10, 1964; also published in High Temperature Refractory Metals, Metallurgical Society Conferences, Vo1. 34, Part 2, Interscience, 1966.

42. T.F. Lyon, "Low Pressure 0xidation of Cb-1 Zr A1loy," Proceedings of 1971 Vacuum Metallurgy Conference, J. Vacuum Science and Technology, Vol. $\underline{8}$, No. 6. VM48 - VM58.

43. R.M. Bonesteel, J.L. Lytton, D.J. Rowcliffe, T.E. Tietz, Recovery and Internal Oxidation of Columbium and Columbium Alloys, AFML-TR-66-253, August, 1966 .

44. T.K. Roche, "Effect of Degree of Vacuum on the Slow-Bend Creep Behavior of Columbium- $0.6 \%$ Zirconium at $1000^{\circ} \mathrm{C}$, "Refractory Metals and A1loys III Applied Aspects, Metallurgical Society Conferences, Vol. 30, Edited by R.I. Jaffee, Corgon and Breach, 1966. 901-916. 
45. J. Stoop, P. Shahinian, The Effect of Nitrogen on the Tensile and CreepRupture Properties of Niobium, NRL-6464, October 31, 1966.

46. C.T. Liu, H. Inouye, Mechanical Properties and Interstitial Contaminants in a Molybdenum-Base ATloy, TZM, ORNL-TM-4238, August 1973.

47. A.K. Mukherjer, J.W. Martin, "The Effect of Nitriding Upon the Creep Properties of Some Molybdenum Alloys," J. Less-Common Metals, Vol. 5 , 403-410. 1963.

48. C.T. Liu, H. Inouye, R.W. Carpenter, "Structure and Mechanical Properties of Internally 0xidized Ta-8W-2Hf (T-111) Alloy," Met. Trans. Vol. 4 , 1839-1850. 1973.

49. D.T. Bourgette, H.E. McCoy, "A Study of the Vaporization and Creep-Rupture Behavior of Type 316 Stainless Steel," Trans ASM, Vol 59, 324-339. 1966.

50. R.A.U. Huddle, "The Influence of HTR Helium on the Behavior of Metals in High Temperature Reactors," Effects of Environment on Material Properties in Nuclear Systems, British Nuclear Energy Society Conference on Corrosion, 1971. 203-212.

51. R. Darras, Ibid. 230.

52. R. Nieder, G. Ivens, "The Effect of Coolant Gas Impurities and Fast Neutron Dose on the Materials of the Primary Circuit of the AVR, "Ibid.

53. High Temperature Reactor Project Dragon, 8th Annual Report 1966-67, 0.E.C.D., European Nuclear Energy Agency, 39-49. 1967.

54. H.E. McCoy, "The Influence of Various Gaseous Environments on the CreepRupture Properties of Nuclear Materials Selected for High-Temperature Service," Proceedings of the Conference on the Corrosion of Reactor Materials, Vol. 1, Vienna: International Atomic Energy Agency, 1962. 263-296.

55. W.T. Chandler, R.J. Walter, "Hydrogen Effects in Refractory Metals," Refractory Metal Alloys, Plenum Press. New York, 1968. 197-249.

56. G. Horz, "Mechanisms and Kinetics of Absorption and Desorption Reactions in Systems of Refractory Metals with Nitrogen, Oxygen, or Carbon," Metallurgical Transactions, 3, 3069. 1972.

57. H. Inouye, Interactions of Refractory Metals with Active Gases in Vacua and Inert Gas Environments, ORNL-4312, 1968.

58. J.N. Ong, Jr., and W.M. Fasse11, Jr., "Kinetics of Oxidation of Columbium and Other Refractory Metals," Corrosion, 18, 382t. 1962.

59. C.A. Barrett, Absorption Rate Sticking Probabilities for Oxygen on Columbium and Dilute Columbium-Zirconium Alloys, NASA TN D 4885. 1967.

60. L.S. Darken, R.W. Gurry, Physical Chemistry of Metals, McGraw-Hi11, NY 1953. 447-449. 
61. F.N. Rhines, W.A. Johnson, W.A. Anderson, "Rates of High Temperature Oxidation of Dilute Copper Alloys," Trans. AIME, Vol. 147, 205-221. 1942.

62. CTR Engineering Systems Study Review Meeting, WASH-1278, September 1973.

63. S. Dushman, J.M. Lafferty, Scientific Foundations of Vacuum Technique, John Wiley and Sons, Inc., NY 1962.

64. J.E. Antil1, K.A. Peakal1, J.B. Warburton, "The Transfer of Carbon from an Inert Gas Containing Carbon Monoxide or Methane to Iron and Nickel-Base Alloys," Op.Cit. 50, 187. 
No. of

Copies

OFFSITE

A. A. Churm

AEC Chicago Patent Group

U.S. Atomic Energy Commission 9800 S. Cass Avenue

Argonne, IL 60439

D. S. Beard

AEC Controlled Thermonuclear

Research Division

Division of Research

Washington, D.C. 20545

R. W. Bussard

AEC Controlled Thermonuclear Research Division

Division of Research

Washington, D.C. 20545

S. 0. Dean

AEC Controlled Thermonuclear

Research Division

Division of Research

Washington, D.C. 20545

3 W. C. Gough

AEC Controlled Thermonuclear

Research Division

Division of Research

Washington, D.C. 20545

R. L. Hirsch

AEC. Controlled Thermonuclear

Research Division

Division of Research

Washington, D.C. 20545

L. K: Price

AEC Controlled Thermonuclear

Research Division

Division of Research

Washington, D.C. 20545
No. of

Copies

OFFSITE

A. W. Triyëlpiece

AEC Controlled Thermonuclear

Research Division

Division of Research

Washington, D.C. 20545

E. Ziurys

AEC Controlled Thermonuclear

Research Division

Division of Research

Washington, D.C. 20545

K. M. Zwilsky

AEC Controlled Thermonuclear

Research Division

Division of Research

Washington, D.C. 20545

G. A. Kolstad

AEC Division of Physical

Research

Washington, D.C. 20545

M. E. Rose

AEC Division of Physical

Research

Washington, D.C. 20545

3 AEC Technical Information Center

M. S. Kaminsky

Argonne National Laboratory

9700 South Cass Avenue

Argonne, IL 60439

P. M. Persiani

Argonne National Laboratory

9700 South Cass Avenue

Argonne, IL 60439 
No. of

Copies

OFFSITE

M. Petrick

Engineering and Technology

Division

Argonne National Laboratory 9700 South Cass Avenue

Argonne, IL 60439

W. E. Parkins, Manager

Atomics International

Component Engineering and

Technology Division

North American Rockwell

P.0. Box 309

Canoga Park, CA 91304

D. Gurinsky

Brookhaven National

Laboratory

U.S.A.E.C.

Brookhaven Area Office

Upton, NY 11973

S. Pearlstein

Brookhaven National

Laboratory

U.S.A.E.C

Brookhaven Area Office

Upton, NY 11973

J. R. Powe 11

Brookhaven National

Laboratory

U.S.A.E.C.

Brookhaven Area Office

Upton, NY 11973

A. J. Impink, Jr.

Carnegie Mellon University

Pittsburgh, PA 15213

R. A. Gross

Plasma Research Laboratory

Columbia University

New York, NY 10027
No. of

Copies

OFFSITE

G. R. Hopkins

Gulf General Atomic

P.0. Box 1111

San Diego, CA 92112

T. B. Taylor

International Research and

Technology Corporation

Suite 610

1225 Connecticut Avenue, N.W.

Washington, D.C. 20008

Zeinab Sabri

Iowa State University

261 Sweeney Hall

Nuclear Engineering Department

Ames, IA 50010

R. Borg

Lawrence Livermore Laboratory

P.0. Box 808

Livermore, CA 94550

A. Carl Haussmann

Lawrence Livermore Laboratory

P.0. Box 808

Livermore, CA 94550

R. F. Post

Lawrence Livermore Laboratory

P.0. Box 808

Livermore, CA 94550

C. J. Taylor

Lawrence Livermore Laboratory

P.0. Box 808

Liverinore, CA 94550

R. Werner

Lawrence Livermore Laboratory

P.0. Box 808

Livermore, CA 94550

L. L. Wood

Lawrence Livermore Laboratory

P.0. Box 808

Livermore, CA 94550 
No. of

Copies

OFFSITE

D. J. Dudziak

Los Alamos Scientific

Laboratory

CTN Research

P.0. Box 1663

Los Alamos, NM 87544

D. B. Henderson

Los Alamos Scientific

Laboratory

CTN Research

P.0. Box 1663

Los Alamos, NM 87544

J. A. Phillips

Los Alamos Scientific

Laboratory

CTN Research

P.0. Box 1663

Los Alamos, NM 87544

F. L. Ribe

Los Alamos Scientific

Laboratory

CTN Research

P.0. Box 1663

Los Alamos, NM 87544

L. Stewart

Los Alamos Scientific

Laboratory

CTN Research

P.0. Box 1663

Los Alamos, NM 87544

J. Williams

Los Alamos Scientific

Laboratory

CTN Research

P.0. Box 1663

Los Alamos, NM 87544

Bruno Coppi

Department of Physics

Massachusetts Institute of

Technology

Cambridge, MA 02139
No. of

Copies

OFFSITE

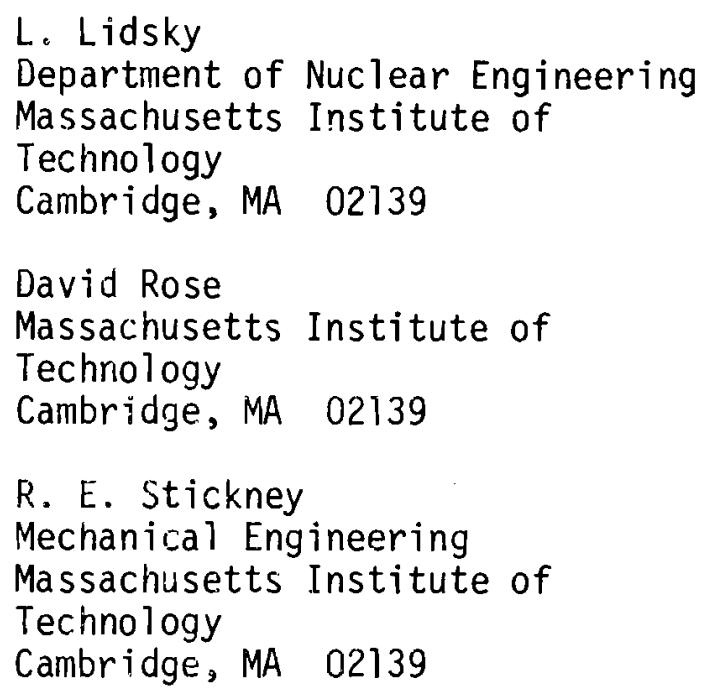

L. Lidsky

Department of Nuclear Engineering

Massachusetts Institute of

Technology

Cambridge, MA 02139

David Rose

Massachusetts Institute of

Technology

Cambridge, MA 02139

R. E. Stickney

Mechanical Engineering

Massachusetts Institute of

Technology

Cambridge, MA 02139

J. J. Reinmann

NASA - Lewis Research Center

21000 Brookpark Rd.

Cleveland, $\mathrm{OH} \quad 44135$

Vincent Arp

National Bureau of Standards

Cryogenics Division

Boulder, CO 80302

A. P. Fraas

Oak Ridge National Laboratory

P.0. Box $Y$

Oak Ridge, TN 37830

J. Rand McNally, Jr.

Oak Ridge National Laboratory

P.0. Box Y

Oak Ridge, TN 37830

D. Steiner

Oak Ridge National Laboratory

P.0. BoX Y

Oak Ridge, TN 37830

R. A. Huse

Public Service Electric and

Gas Co.

80 Park Place

Newark, NJ 07101 
No. of

Copies

OFFSITE

R. G. Mills

Princeton University

P.0. Box 451

Princeton, NJ 08540

E. C. Tanner

Princeton University

P.0. Box 451

Princeton, NJ 08540

C. R. Finfgeld

Roanoke College

Salem, VA 24153

M. Kristiansen

Texas Tech. University

Lubbock, TX 79409

A. F. Haught

United Aircraft Research

Laboratories

United Aircraft Corporation

East Hartford, CT 06108

L. Levine

U.S. Naval Research Laboratory

Washington, D.C. 20390

C. Z. Serpan, Jr.

U.S. Naval Research Laboratory

Washington, D.C. 20390

Francis Chen

University of Cal ifornia

Department of Electrical

Engineering

Los Angeles, CA 90024

A. J. Lichtenberg

University of California

Electronics Research

Laboratory

College of Engineering

Berkeley, CA 94720
No. of

Copies

OFFSITE

C. D. Hendricks

University of Illinois

Nuclear Engineering

Laboratory

Urbana, IL 61801

G. H. Miley

University of Illinois

Nuclear Engineering

Laboratory

Urbana, IL 61801

Terry Kammash

University of Michigan

Nuclear Engineering Department

Ann Arbor, MI 48105

Dean Abrahamson

University of Minnesota

School of Public Affairs

Room 309

Social Science Building

Minneapolis, MN 55455

W. G. Davey

University of Texas

Department of Physics

Austin, TX 78712

E. Linn Draper, Jr.

University of Texas

Department of Physics

Austin, TX 78712

W. E. Drummond

University of Texas

Department of Physics

Austin, TX 78712

Abraham Hertzberg

University of Washington

Aerospace Research Laboratory

316 Guggenheim

Seattle, WA 98105 
No. of Copies

OFFS ITE

A. L. Babb

University of Washington

Nuclear Engineering Department

Seattle, WA 98105

R. Conn

University of Wisconsin

Nuclear Engineering Department

Madison, WI 53706

G. L. Kulcinski

University of Wisconsin

Nuclear Engineering Department

Madison, WI 53706

C. W. Maynard

University of Wiscons in

Nuclear Engineering Department

Madison, WI 53706

A. F. Haught

United Aircraft Research

Laboratories

United Aircraft Corporation

East Hartford, CT 06108

E. E. Donaldson

Washington STate University

Department of Physics

Pullman, WA 99163

\section{ONSITE}

AEC Chicago Patent Group

R. M. Poteat

2 AEC Richland Operations Office

P. G. Holstead

B. M. Melton

41 Battelle-Northwest

J. L. Brimhall

T. D. Chikalla

L. A. Charlot

D. L. Condotta

S. D. Dahlgren

R. L. Ditlon

K. Drumheller
No. of

Copies

ONSITE

Battelle-Northwest (cont)

J. W. Finnigan

S. Goldsmith

J. Greenborg

0. K. Harling

R. E. Heineman

A. B. Johnson, Jr. (5)

R. S. Kemper

B. R. Leonard, Jr.

R. P. Marshall

R. E. Nightingale

L. T. Pedersen

L. C. Schmid

G. L. Tingey

R. E. Westerman (10)

W. C. Wolkenhauer

Technical Publication (1)

Technical Information (5) 